\title{
THE KNOWN AND UNKNOWN ABOUT MARINE BIODIVERSITY IN ECUADOR (CONTINENTAL AND INSULAR)
}

\section{LO CONOCIDO Y DESCONOCIDO DE LA BIODIVERSIDAD MARINA EN EL ECUADOR (CONTINENTAL E INSULAR)}

\author{
Manuel Cruz ${ }^{1-3}$, Nikita Gabor ${ }^{2}$, Elba Mora ${ }^{2-3}$, Roberto Jiménez ${ }^{3} \&$ James Mair $^{4}$ \\ ${ }^{1}$ Instituto Oceanográfico de la Armada, ${ }^{2}$ Instituto Nacional de Pesca, ${ }^{3}$ Universidad de Guayaquil, Ecuador and Herriot \\ Watt University, Edinburgh, Scotland ${ }^{4}$
}

\begin{abstract}
Ecuador has a high diversity of ecosystems in its coastal and marine territory with beaches, bays, estuaries, cliffs, coastal lagoons and rocky coasts being the most representative. So far, 1,859 marine species have been identified in Ecuador. Of these, 1380 species of non-commercial marine invertebrates and vertebrates, belonging to 8 Phyla and distributed in 25 groups or classes, occur along the coast of Ecuador. These are: Protozoans, 9 groups: Oceanic and estuarine Diatoms, Cyanophyta, Chlorophyta, Dinoflagellates, Coccolithophorida, Silicoflagellates, Euglenophyta, Tintinnids and planktonic and benthic Foraminifera; Cnidaria, 2 classes: Hydromedusae and Scyphomedusae; Mollusca, 5 classes: Wood-boring molluscs and rock-boring and benthic bivalves; Gasteropoda: (Thecosomatans, Pteropods, Heteropods and benthic species, Polyplacophora, Scaphopoda and Cephalopoda); Annelida, 1 group: benthic Polychaeta; Arthropoda, 1 class: Crustacea (Cirripedia, Anomura, Brachyuran, Euphausiids); Chaetognatha, 1 group; Echinodermata, 4 classes: Asteroidea, Ophiuroidea, Echinoidea and Holothuroidea; Chordata, 2 classes: Marine mammals and birds. Both the biodiversity of the meiobenthos of the Gulf of Guayaquil and that of the inter-tidal zone are presented. The 479 demersal species of commercial importance are grouped in 4 Phyla (Chordata, Arthropoda, Mollusca, and Echinodermata), 41 orders, 143 families and 258 genera. The phylum Chordata represented by fish is the most diverse group on the coast with 270 species from 142 genera, 63 families, and 22 orders, the order Perciformes being the best represented with 143 species. Molluscs form the next biggest group with 110 species. In general, the biggest biodiversity of species seems to be in the Gulf of Guayaquil, the main estuary of Ecuador. However, this may be because that area has been better studied than the others. The work presented is mainly the result of research carried out by Equatorians and thus cannot be claimed to include the whole of the current information about marine biodiversity in Ecuador.
\end{abstract}

KEYwords: Biodiversity, pelagic, demersal, benthic, Gulf of Guayaquil.

\section{RESUMEN}

Ecuador tiene una diversidad alta de ecosistemas en todo su territorio marino-costero donde las playas, bahías, estuarios, acantilados, lagunas costeras y las costas rocosas son los de mayor representatividad. Hay un total de 1.859 especies marinas que han sido identificadas para Ecuador, que incluye especies comerciales y no comerciales. Se conoce que 1.380 especies de invertebrados y vertebrados marinos no comerciales pertenecen a 8 Phyla, los cuales han sido reportados para el Pacífico ecuatoriano, distribuidos en 25 grupos o clases de organismos que son: Protozoos: 9 grupos: Diatomeas oceánicas y estuarinas, Cyanophyta, Chlorophytas, Dinoflagelados, Coccolitophorida, Silicoflagelados, Euglenophyta, Tintinnidos, Foraminíferos planctónicos y bentónicos, Cnidaria, 2 clases: Hydromedusas y Scyphomedusas; Mollusca, 5 clases: Bivalvos (Bentónicos, perforadores de maderas y rocas), Gasteropods (Pterópodos, Thecosomados y Heterópodos), Poliplacophora, Scaphopoda y Cephalopoda; Annelida, 1 grupo: Poliquetos bentónicos; Arthropoda, 1 clase: Crustacea: (Cirripedia, Anomura, Brachyuran, Euphausiacea); Chaetognatha, 1 grupo; Echinodermata, 4 clases: Asteroidea, Ophiuroidea, Echinoidea y Holothuroidea; Chordata, 2 clases: Mamíferos y aves. Las 479 especies demersales registradas se agruparon en cuatro Phylum (Chordata, Arthropoda, Mollusca y Echinodermata): 258 géneros, 143 familias y 41 órdenes. El Phylum (Chordata) representado por los peces es el grupo más diverso en la costa con 270 especies, agrupadas en 142 géneros, 63 familias y 22 órdenes, siendo el órden Perciformes 
el más representativo con 143 especie. El registro de 479 especies para cuatro subáreas permitió determinar la presencia de cada especie, así como el de los géneros, familias, y órdenes para el phylum en cada subárea. De los cuatro phyla considerados en este estudio, los peces y los moluscos corresponden a los grupos mejor representados en la costa del Ecuador, con una riqueza de 270 y 110 especies, respectivamente. En general la biodiversidad más grande de especies se encuentra en el Golfo de Guayaquil, el estuario principal del Ecuador. Sin embargo es necesario indicar que este ecosistema ha sido el más estudiado en relación con los otros, razón por la que, probablemente, subestime a los otros ecosistemas.

PALABRAS ClaVEs: Biodiversidad, pelágico, demersal, bentónico, Golfo de Guayaquil.

\section{INTRODUCTION}

Ecuador has a high diversity of marine ecosystems; beaches, bays, estuaries, cliffs, coastal lagoons, and rocky coasts are the most typical (Gabor 2002). They provide not only habitats for a wide range of biota but also other types of marine resources. There is a great variety of fish, crustaceans, mollusks, and algae as well as numerous invertebrates and microorganisms which co-exist in harmony, in spite of the disparate characteristics of each species or group.

Knowledge about these marine and coastal species is of great importance, especially as they are often exposed to exceptional plankton blooms and subject to high environmental variability caused by natural phenomena such as El Niño and La Niña. Information about the diversity of marine organisms in Ecuador had been very limited but, in the last few years, the scientific community has recognized it as a high-priority and this has led to new, upgraded revisions of the taxonomy of the various groups.

Studies of commercial marine species in Ecuador began in 1960 when the National Fisheries Institute (INP) started an evaluation of the commercial fisheries in the Ecuadorian Sea. Later, with the creation of the Oceanographic Institute of the Navy (INOCAR) and the graduation of the first group of biologists from the Faculty of Natural Sciences, both in 1972, marine research, initially mainly on phytoplankton, primary productivity, and zooplankton, began.

The first studies involved the taxonomy of diatoms, dinoflagellates, silicoflagellates, coccolithophorids, tintinnids, planktonic, and benthic foraminifera, chaetognatha, euphausiids, and benthic mollusks. Later, these were extended to include benthic polychaetes, marine copepods, Pteropods, Heteropods, and wood and rock boring mollusks. Research on many of these groups present in the Gulf of Guayaquil was carried out by doctoral students at the University of Guayaquil.

Few studies have been made in Ecuador with the specific objective of obtaining data on marine biodiversity. Existing information is limited and dispersed. Most of the research carried out by the National Fishing Institute has been directed towards demersal and pelagic fish resource assessments from surveys of the abundances and distributions of the main species of fish in the shelf and slope areas of the continental and insular coasts of Ecuador. Cobo \& Massay (1969) reported the presence of 344 species of fish distributed in 206 genera and 92 families. Later on, 419 species of commercial fish (244 genera, 111 families) were identified by Massay (1983). Mora (1990) identified 23 species of mollusks of commercial importance from 114 species of bivalves found in Ecuador. There are also 17 species of crustaceans with high commercial value (Correa 1993).

A recent study done in the Gulf of Guayaquil has shown that demersal species vary with depth (Chalén $\&$ Sandoval 2002). Also in this Gulf, 14 groups of estuarine meiobenthos from the phylum level to certain groups at the class level were reported. Others, at the order level, will require more specialized and expensive methodology for their identification (Cruz 1998).

In the Galapagos Islands, most of the research at the Charles Darwin Research Station (ECCHD) has focused on terrestrial biodiversity. Of the marine biota, the vertebrates are the best known because of their commercial value. Few studies on marine invertebrates have been made, such as black coral and the sea cucumber Stichopus fuscus, as well as of some mollusks, echinoderms and, recently, crustaceans.

The present paper provides a reference base of the diversity and distribution of marine fish, crustaceans, 
mollusks, and echinoderms found in Equatorian waters and, thus, a foundation for future zoogeographical studies. It gathers together the results of marine biodiversity reported by foreign scientists as well as by Equatorians working in the main national research institutes. Among these are the Faculty of Natural Sciences at the University of Guayaquil, which does studies on marine biodiversity in the inter-tidal zone; the National Fisheries Institute (INP) that studies both marine and freshwater resources, and the Oceanographic Institute of the Navy (INOCAR), which carries out research on all aspects of oceanography in the Equatorian waters, mainly around the Galapagos
Islands. It is hoped, that this paper represents a referential framework for extending our knowledge in the future.

\section{A. OCEANOGRAPHY AND CURRENT ASPECTS}

The Pacific Ocean off the coast of Ecuador is characterized as an area of transition between the warm, lowsalinity tropical water to the north and the cold, saline, subtropical water of the Humboldt Current to the south off Peru. Between these water masses, there is an area denominated the Equatorial Front with strong thermal/salinity gradients which undergo marked seasonal variations (Cucalon 1986) (Fig. 1).

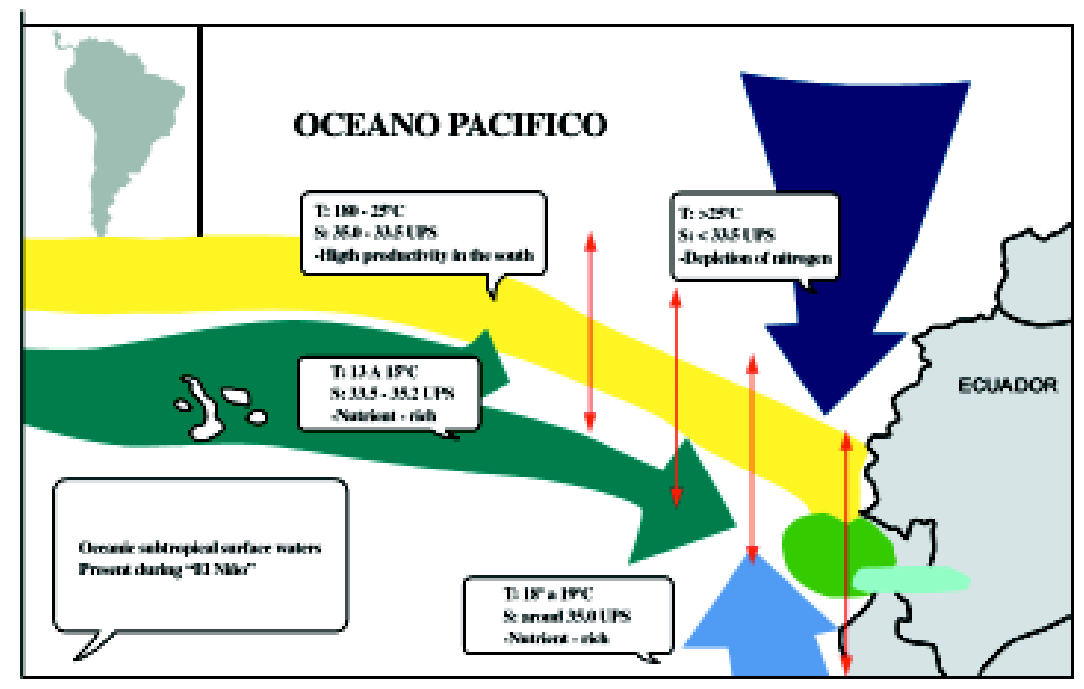

Ecuatorial Subbuface Current

$\square$ Equatorial Front

Main catchment basin

Gulf of Guayaqui

$\square$ Upwelings

Humboldt Coastal Current

EI Nine Casstal Current

FIGURE 1. The main currents and water masses which influence marine biodiversity off Ecuador.

FIGURA 1. Las principales corrientes y masas de agua con influencia en la biodiversidad frente a Ecuador. 
Additionally, the frontal area is characterized by the periodical occurrence of "El Niño", the warm phase of ENSO (El Niño Southern-Oscillation). During this, anomalously high temperatures are observed in the upper layer of the ocean. Other changes in the ocean-atmospheric system are also evident, many of which affect the primary, secondary, and tertiary trophic levels, as well as the coastal climate. Its effects are similar to an intertidal increase in sea level caused by a storm (Arriaga 1997). An equally important event is that of "La Niña" which is characterized mainly by sea temperatures that are below the mean value and also has repercussions on the distribution of both coastal and oceanic resources (Arriaga 1999).

\section{b. MARINE, COASTAL, AND ISLAND ECOSYSTEMS}

The richness of the marine biodiversity of Ecuador is related to physical conditions that have already been mentioned. The coastal zone receives run-off from 67 watersheds. Of these, 19 are considered to be the most important (Stevenson 1981; Cucalon 1984). The freshwater and nutrients from island are fundamental to the ecological processes that sustain the marine biodiversity. In addition, though, the run-off transports pollutants from terrestrial sources, which are detrimental to the marine environment.

The Galapagos Islands are located 600 miles from mainland Ecuador. There are 14 main islands and many smaller ones that together make up the Galapagos Province. Because of its volcanic origin and its location in a confluence zone of currents in the Pacific Ocean, the Galapagos Islands have a unique climate and a unique flora and fauna. Their most important characteristic is the biodiversity of the marine environment. The scientific history of the islands and the need to conserve the existing ecosystems are well known. These are because: 1) their isolation from the continent allowed localized evolutionary processes to take place, and 2) their geographical location is favorable for future increases in biodiversity.

The main ecosystems, which occur on the continental coast as well as the Galapagos Islands are: mangroves, estuaries, sandy beaches, coral reefs and coastal lagoons. The locations of the various types of ecosystem in 3 zones influenced by different oceanic current systems are shown in Fig. 2.

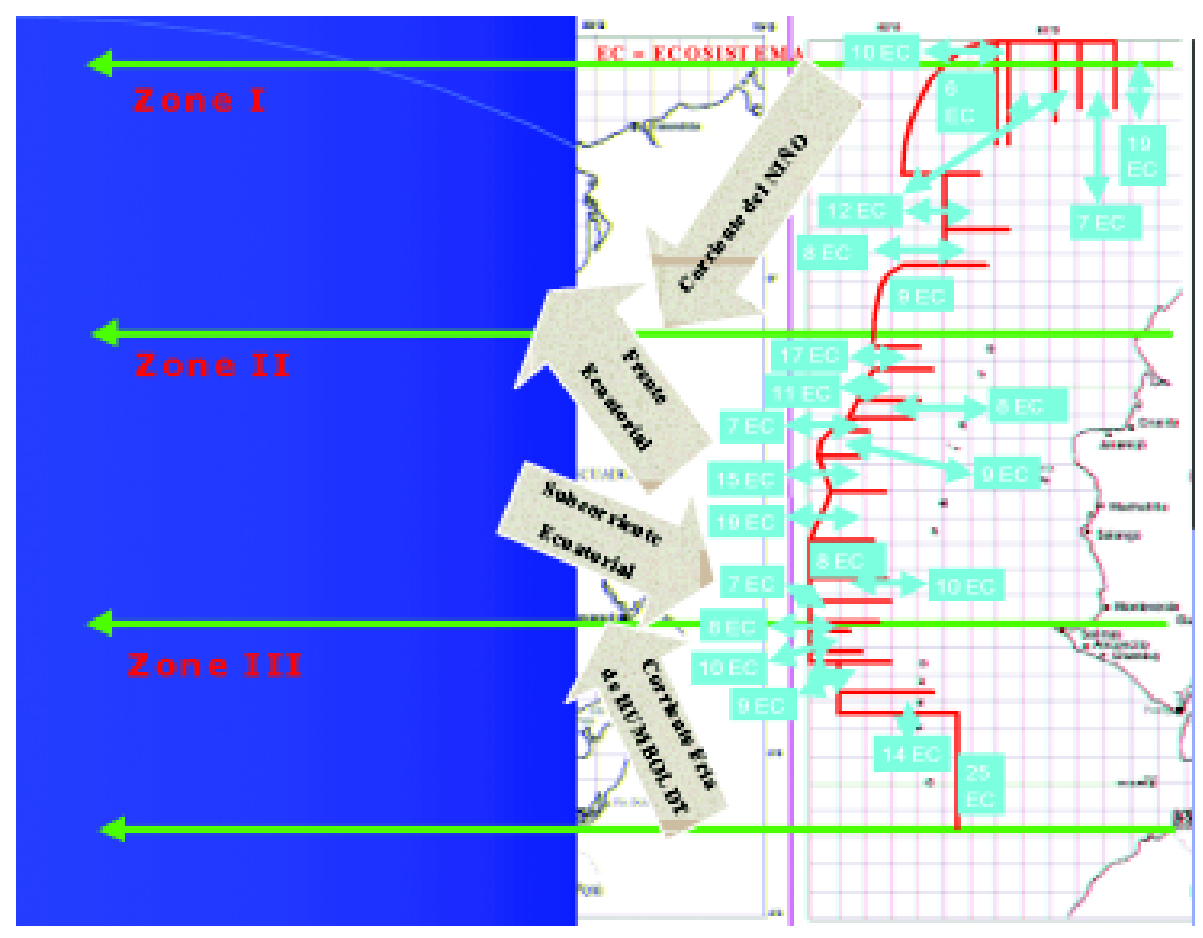

FIGURE 2. Types of ecosystems of Ecuador in 3 zones influenced by different oceanic current systems.

FIGURA 2. Los tipos de ecosistemas ecuatorianos en 3 zonas influenciadas por distintos sistemas oceánicos de corrientes. 
The Mangrove ecosystem plays an important social and ecological role along the coastal areas. Eight species of mangroves are distributed along a narrow band of the outer intertidal zone with salt flats ('salinas') without vegetation in more inland intertidal areas. Estimates indicate that, in 1995, mangroves were present along 13 estuaries covering 149,579 ha; this was $22 \%$ less than in 1969 (Table I). The 121,464 ha of mangroves in the Guayas province have been attributed to the extensive drainage from the Guayas river basin and high rates of evaporation (Schaeffer-Novelli 1983). The sea-ward intertidal zone is colonized by mangroves of the Rhizophoraceae family with Rhizophora harisonii on the perimeter of the shoreline and a mixture of other species just inland from this zone (Citron et al. 1981). Further inland still is a mixed zone of Rhizophora and Avicennia germinans, then a monospecific stand of Avicennia, which yields eventually to shrubs or salt flats with extremely hypersaline soil. A high tidal frequency and river discharge create conditions suitable for mangrove forests covering 1,857 ha in the northern provinces with a tree density (basal area) of $62.4 \mathrm{~m}^{2}$ $\mathrm{ha}^{-1}$. This density exceeds that observed in mangroves in Venezuela, Colombia, Malaysia, and Puerto Rico (Citron 1981). Mangrove forests are less dense in the southern provinces of Ecuador (Citron 1981), particularly those surrounding shrimp ponds (Snedaker et al. 1986).

The loss of mangroves from tropical estuaries in Ecuador had a direct impact on economically important fisheries due to the decrease in habitat and food supply. Zimmerman \& Minello (1989) found that Litopenaeus vannamei and L. stylirrostris inhabit the mangroves in the Estero Salado, but it is not known whether it is the survival or growth of these and other marine organisms, which these habitats enhance. Without further information on the degree of dependence of shrimp larvae and other marine fauna on mangroves for parts of their life cycles, the effect of mangrove clearing on the natu-

TABLE I. Surface area covered by mangroves in the estuaries of Ecuador (1969-1995). (Source: Arriaga 1999).

TABLA I. Area superficial cubierto por mangles en los estuarios ecuatorianos (1969-1995). (Fuente: Arriaga 1999).

\begin{tabular}{lcclcc}
\hline Estuaries & 1969 & 1984 & 1987 & 1991 & 1995 \\
\hline Cayapas & 23,677 & 23,650 & 23,508 & 22,863 & 21,948 \\
Colope & 58 & 23 & 23 & 22 & 22 \\
Atacames & & 52 & 52 & 52 & 52 \\
Muisne & 3,282 & 2,702 & 2446 & 1,340 & 831 \\
Cojimies & 13,124 & 9,917 & 8,467 & 6,029 & 3,652 \\
Pedernales & 0 & 0 & 0 & 0 & 0 \\
Jama & & 40 & 40 & 38 & 26 \\
Canoa & 0 & 0 & 0 & 0 & 0 \\
Briceño & 7 & 0 & 0 & 0 & 0 \\
Chone & 3,973 & 1,673 & 1,040 & 785 & 392 \\
Gilses & 83 & 81 & 81 & 81 & 81 \\
Colonche & 144 & 144 & 144 & 142 & 129 \\
Golfo de Guayaquil & 159,033 & 143,870 & 139,355 & 130,701 & 122,438 \\
\hline Total & 203,625 & 182,157 & 175,157 & 162,054 & 149,570 \\
\hline
\end{tabular}


ral populations in the Guayas River Estuary will remain unknown. Mangrove destruction may also have an indirect effect on fisheries by changing water quality.

\section{c. Pelagic marine Diversity}

A total of 601 species of pelagic organisms have been identified in the Equatorian Sea. Of these, 536 correspond to unicellular organisms represented by 9 groups or taxa (Table II). Diatoms (295 species) are the most abundant (Fig. 4), 182 species being oceanic (Fig. 5) (Jiménez 1983) with Pseudonitzschia delicatissima and Planktoniella sol predominating (Fig. 6) (Torres \& Tapia 2000). There are 113 species of estuarine diatoms, the diatom Chaetoceros affinis being most dominant in the Gulf of Guayaquil (Fig. 7) (Tapia 2002). In this ecosystem, there are also 18 species of Cyanophyta, of which Oscillatoria cortiana is the most abundant (Fig. 8) (Tapia 2002).

The Dinoflagellates are made up of 103 species (Fig. 9) (Pesantes \& Pérez 1982), Blefarocysta splendormaris and Goniodoma polyedricum being the most common (Fig. 10) (Torres 2002). The tintinnids are represented by 50 species (Fig. 11) (Zambrano 1983), with Epiplocyloides reticulata the most dominant (Fig. 12) (Torres 2002).
TABLE II. Number of known pelagic species of from Ecuador.

Tabla II. Cantidad de especies pelágicas conocidas en Ecuador.

\begin{tabular}{lll}
\hline Group & Nr. spp. & Group Total \\
\hline Diatoms & 295 & \\
Dinoflagellates & 103 & \\
Tintinnida & 50 & \\
Coccolithophorida & 37 & \\
Cyanophyta & 18 & \\
Planktonic Foraminifera & 17 & \\
Silicoflagellates & 7 & 536 \\
Chlorophycea & 6 & \\
Euglenophyta & 3 & \\
Pelagic protozoa & & \\
Medusae & 16 & \\
Chaetognatha & 16 & 601 \\
Euphausiacea & 14 \\
Pteropoda & 10 & \\
Heteropoda & 5 & \\
Cephalopoda & 4 & \\
Pelagic Metazoa & & \\
\hline Pelagic Total & & \\
\hline
\end{tabular}

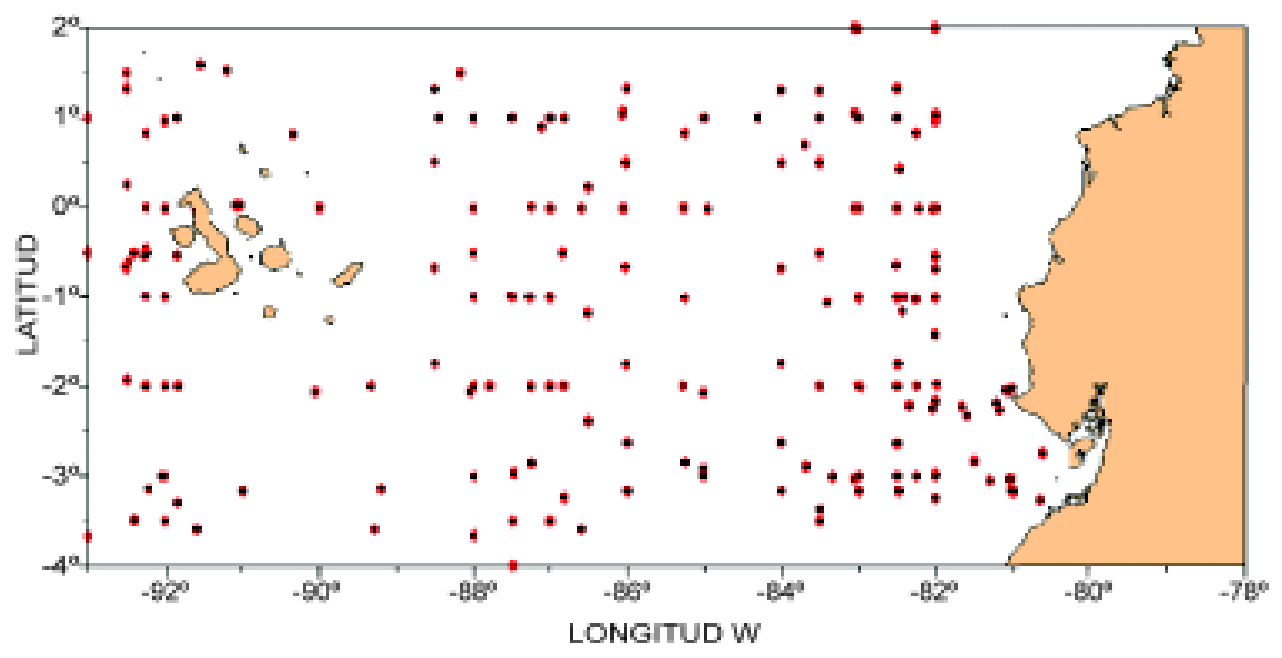

FIGURE 3. Oceanographic stations studied from 1988.

FigURA 3. Estaciones oceanográficas estudiadas desde 1988. 


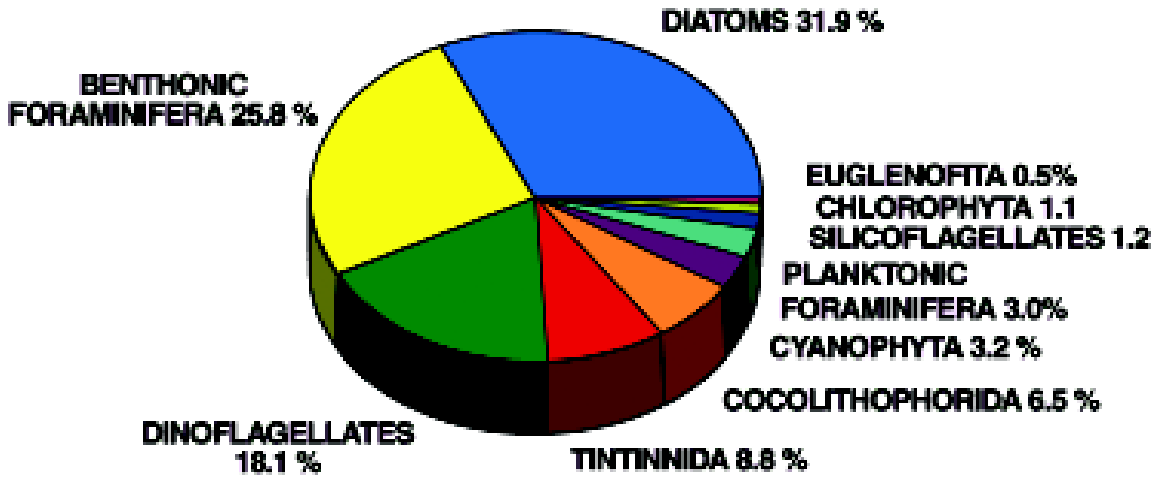

FIGURE 4. Principal groups of 683 species of marine unicellular organisms from the Equatorian Pacific to Oct/2002.

FiguRa 4. Los principales grupos de las 683 especies de organismos marinos unicelulares del Pacífico ecuatoriano hasta octubre del 2002.

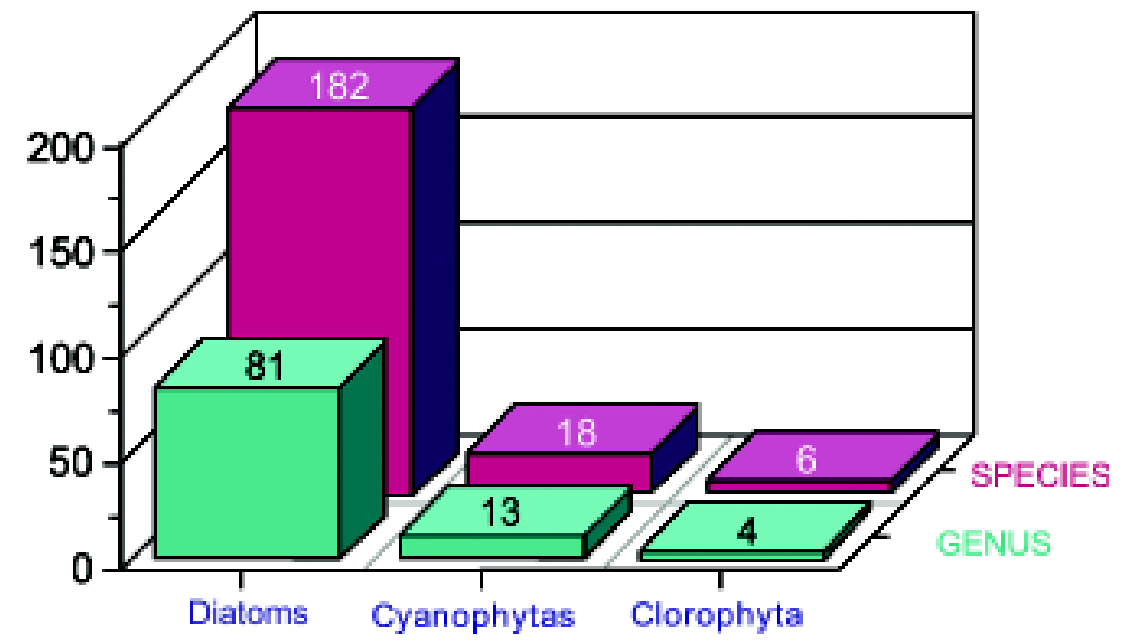

FigurE 5. Species (206) and Genera (98) of marine phytoplankton from the Equatorian Pacific. Oct/2002 (Jiménez 1983).

FiguRa 5. Las especies (206) y géneros (98) de fitoplancton marino del pacífico ecuatoriano. Oct./2002 (Jiménez 1983). 


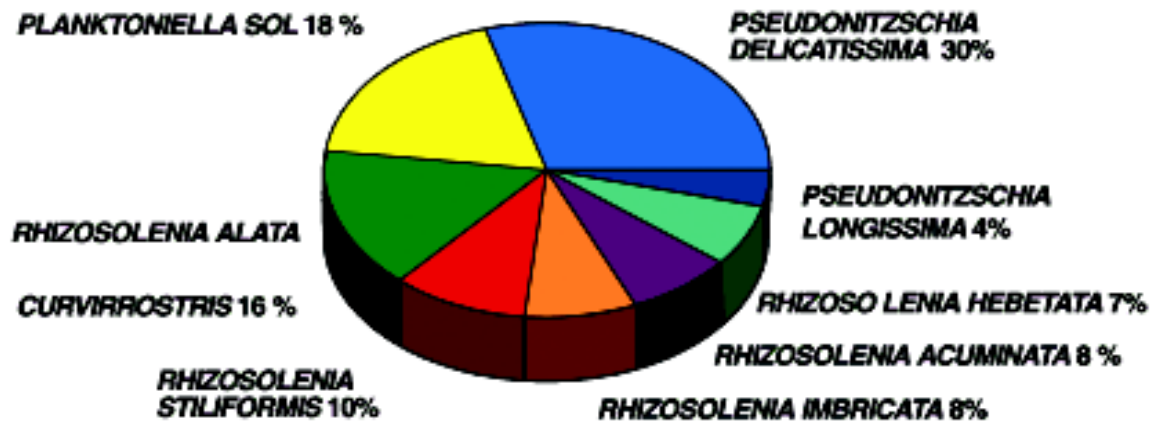

FIgURE 6. The most common oceanic diatoms from Equatorian Pacific, during the warm season (Torres \& Tapia 2000).

FiguRa 6. Las diatomeas más comunes en el Pacífico ecuatoriano durante la temporada cálida (Torres \& Tapia 2000).

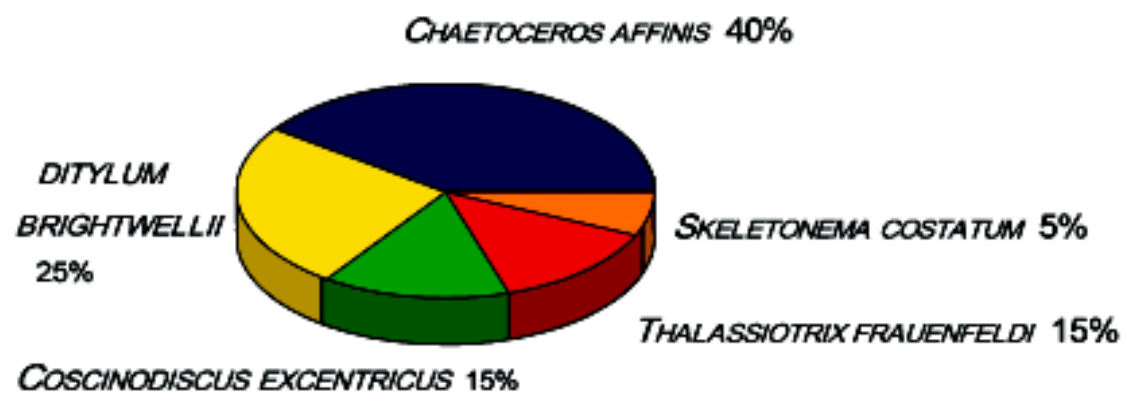

FIGURE 7. The five most abundant species among 113 marine and estuarine diatoms from the Gulf of Guayaquil, Ecuador (Tapia 2002).

FiguRa 7. Las cinco especies más abundantes dentro de113 diátomos marinos y estuarinos del Golfo de Guayaquil, Ecuador (Tapia 2002). 
Gayana 67(2), 2003

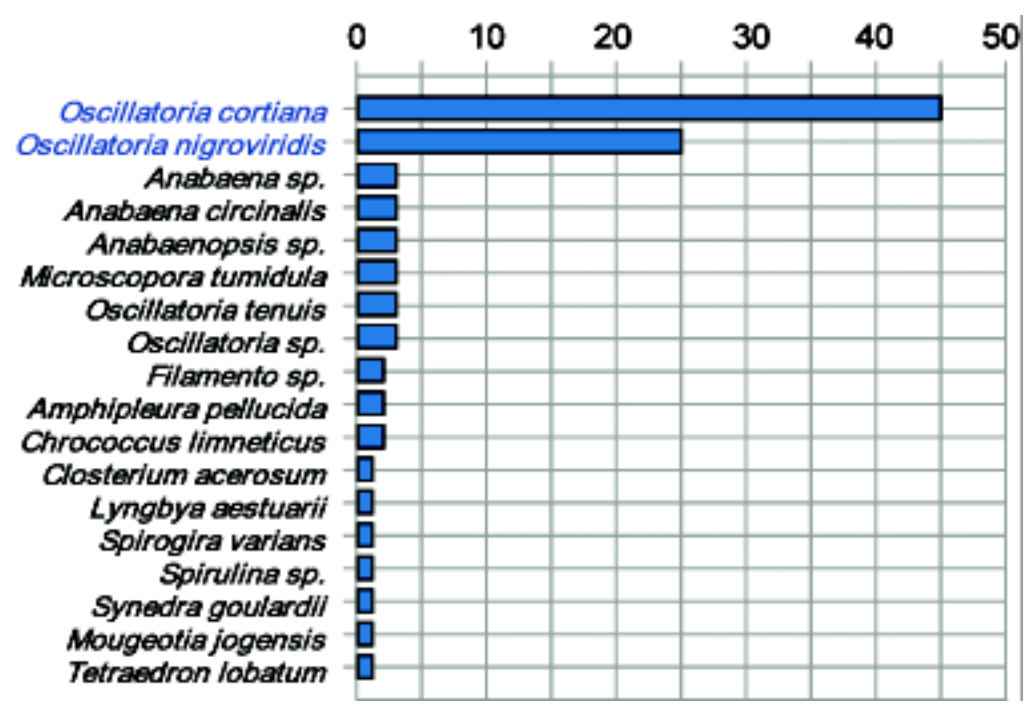

FIGURE 8. Relative abundance of 18 species of estuarine Cyanophyta, from the Gulf of Guayaquil (Tapia 2002).

FiguRa 8. La abundancia relativa de 18 especies de Cyanophyta, estuarina, del Golfo de Guayaquil (Tapia 2002).

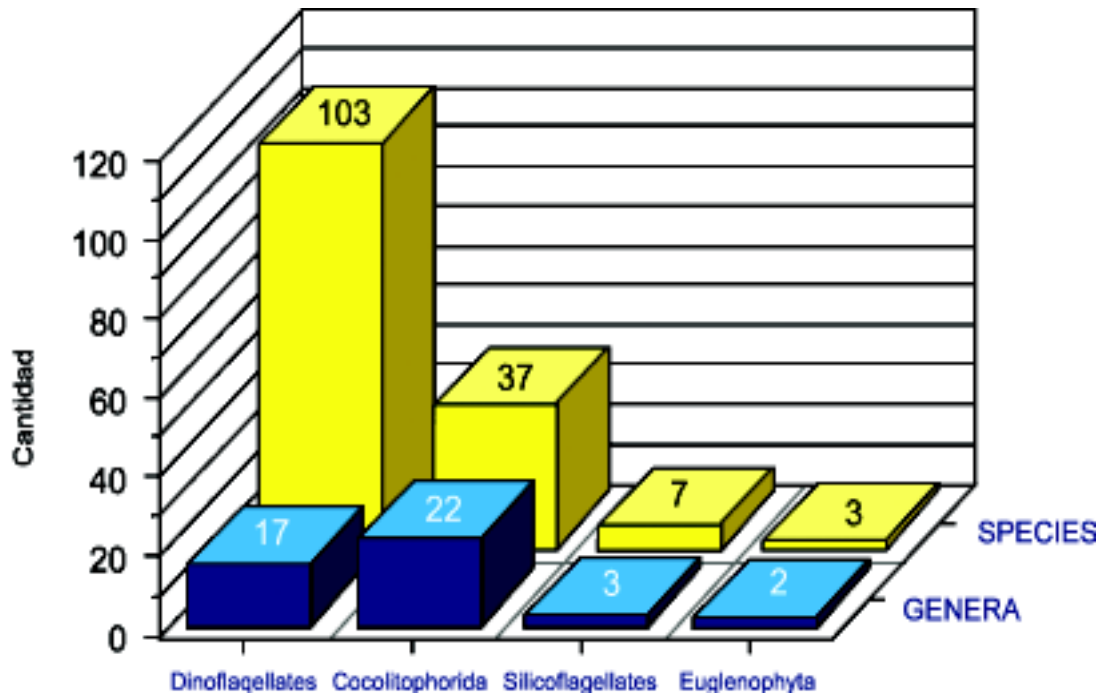

FIGURE 9. Species and genera of marine flagellate protozoa, from the Equatorian Pacific (Pesantes \& Pérez 1982).

Figura 9. Las especies y géneros de los protozoos flagelados marinos del Pacífico ecuatoriano (Pesantes \& Pérez 1982). 


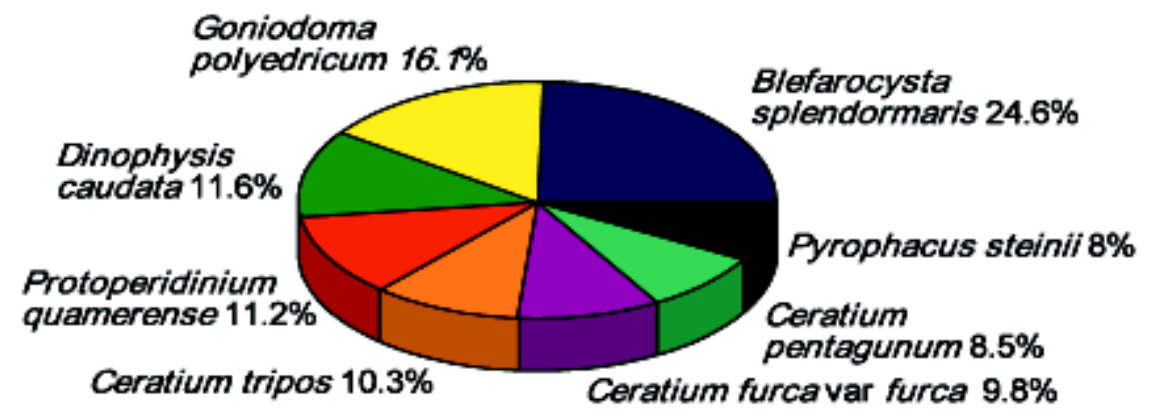

FIGURE 10. The eight most abundant dinoflagellates among 132 species from the Equatorian Pacific (Torres 2002).

Figura 10. Los ocho dinoflagelados más abundantes de las 132 especies en el Pacífico ecuatoriano (Torres 2002).

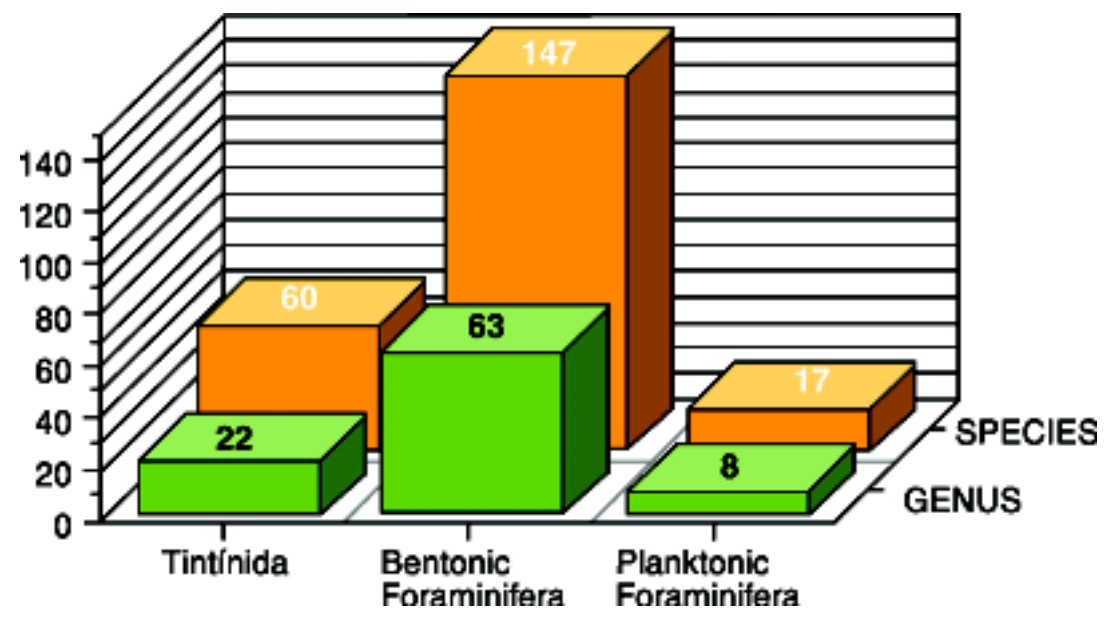

FIGURE 11. Species and genera of marine Tintinnida and Foraminifera from the Ecuadorian Pacific (Zambrano 1983).

Figura 11. Las especies y géneros de Tintínida y Foraminífero del Pacífico ecuatoriano (Zambrano 1983).

Planktonic foraminifera are used in Ecuador as bioindicators of water masses. Seventeen species have been identified (Luzuriaga de Cruz 1976) and, of these, Globocuadrina dutertrei, Globigerinoides ruber, and $G$. sacculifer are the most dominant during the dry season (Fig. 13).

Of the pelagic organisms, metazoarians exhibit the highest diversity and abundance with Sagitta enflata and S. popovicii predominating (Fig. 14) (Naranjo 2002). Another abundant group in the Equatorian Sea are the jellyfish with 16 species (Figure 15) (Segura-Puertas 1984). The Euphausiids with 14 species (Fig. 16) (Cornejo de Gonzalez 1976) are also important in the marine ecosystem with Euphausia lamelligera and E. tenera dominating.

Five species of Heteropods are used as bio- 


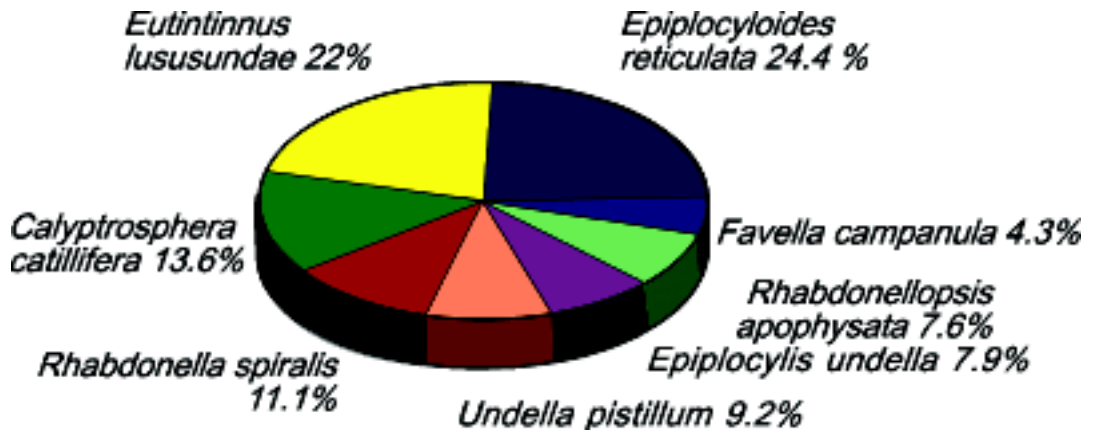

FiguRE 12. The eight most abundant Tintinnida among 26 species from the Ecuador (Torres 2002).

Figura 12. Los ocho Tintínida más abundantes de las 26 especies en Ecuador (Torres 2002).

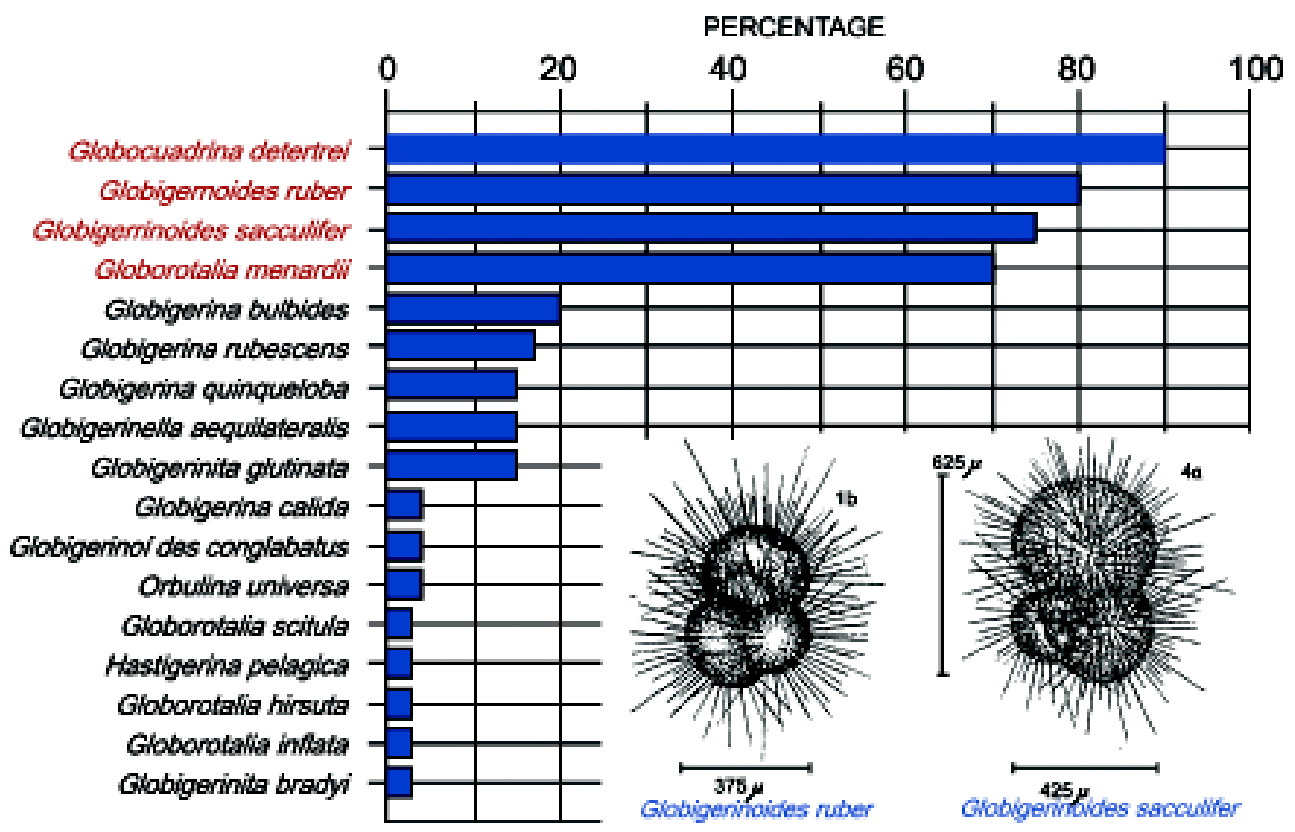

FIGURE 13. Relative abundance of the planktonic oceanic Foraminifera (17 spp.), from Equatorian Pacific as found during the month of December (Luzuriaga de Cruz 1976).

Figura 13. La abundancia relativa de foraminífera planctónica y oceánico (17 spp.) del Pacífico ecuatoriano en el mes de diciembre (Luzuriaga de Cruz 1976). 


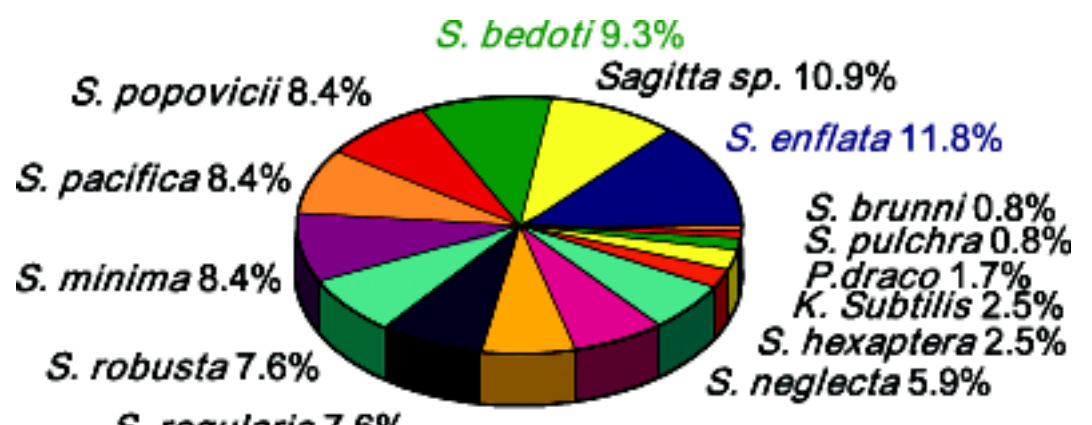

S. regularis $7.6 \%$

S. peruviana $6.7 \%$

\section{S. bipunctata $6.7 \%$}

FIGURE 14. Relative frequencies of 16 species of chaetognaths in the Ecuadorian Pacific (Naranjo 2002).

Figura 14. Las frecuencias relativas de 16 especies de chaquetognatos en el Pacífico ecuatoriano (Naranjo 2002).
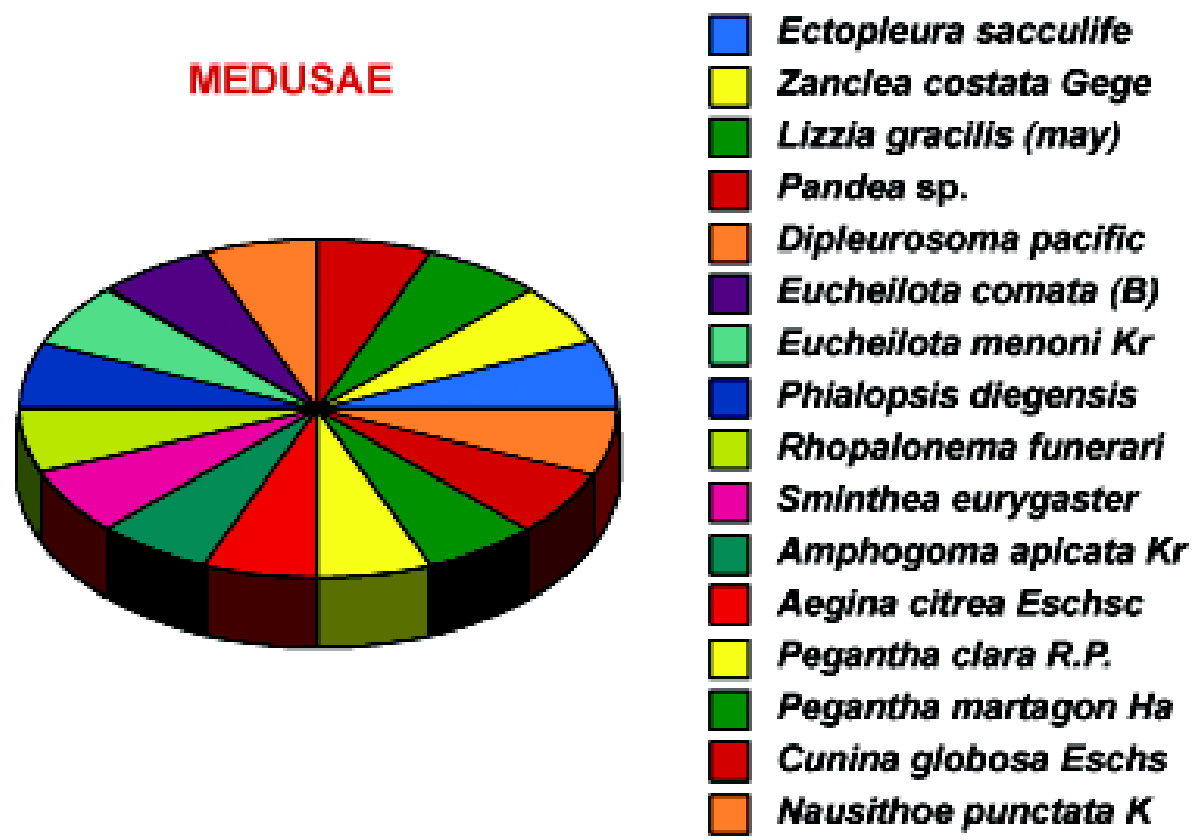

Figure 15. Sixteen (16) species of medusae from the Equatorian Pacific (Segura-Puertas 1984).

FIGURA 15. Dieciseis (16) especies de medusae del Pacífico ecuatoriano (Segura-Puertas 1984). 
indicators of water masses and of El Niño events; Atlanta gaudichaudi is the most common (Fig. 17) (Cruz 2002). In the same way, 10 species of the Pteropods, tecosomates, are used as bioindicators of the marine eco-system. Creseis virgula, is dominant and it is always present indicating the intrusion of oceanic waters near the coast (Fig. 18) (Cruz 2002).

Four species of cephalopods have been recorded in Equatorian waters. The most abundant is the giant squid Dosidicus gigas (Fig. 19) (Pacheco et al. 1994).

Small pelagic species of fish are distributed from the Gulf of Guayaquil to off the coast of the province of Manabi. There has been a decline in the abundance and landings of these commercial fish as well as in the biomass of the sardine (Sardinops sagax), 'pinchagua' (Opisthonema spp.), 'chuhueco' (Cetengraulis mysticetus), and anchovy (Engraulis ringens).

The larger pelagic fishes, which are transzonal, migratory species and exploited by the fishing industry include tuna (Thunnus albacares, T. obesus and Katsuwonus pelamis), swordfish (Xiphias gladius), marlin (Istrophorus platypteru), and 'picudos' (Makaira mazarra and M. indica).

\section{d. Marine benthic Diversity}

To date, 675 species of benthic marine invertebrates have been identified. Of these, the mollusks are the most abundant with 256 species. Among them, the gastropods are the most common and represent $77 \%$ of the group (Fig. 20) (Hickman \& Finet 1998). Their shell debris forms the sea- bottom of the sea around the Galapagos Islands. One of the most common and widely distributed species, both on the continent and in the Galapagos Islands, is Thais melones.

The protozoans, denominated by benthic Foraminifera, are the second largest group with 147 species; Bulimina pulchela and Cibicides bertheloti cf boueana are the most common (Fig. 21) (Gualancañay 1975).

Wood boring mollusks are well known for the damage they cause to boats and jetties. There are 14 species of such bivalves, of which Teredo furcifera (Fig. 22) (Cruz 1992) is the one that causes most problems in the ports of Manta, Salinas and the Galapagos Islands.

There are also 7 species of rock boring bivalves causing erosion of the rocky substrates of the Equatorian coast. Petricola denticulata, is the most frequently observed (Fig. 23) (Cruz 2002). Forty-two species of benthic polychaetes from the intertidal and sublithoral areas have been identified, 24 being Errant and 18 Sedentary (Fig. 24) (Villamar 1983). The Echinoderms are very abundant in the Galapagos Islands with 69 reported species of which the Ophiuroidea are the more common (Fig. 25) (Hickman 1998). Recently, it was reported that 140 of the species of marine invertebrates found in Ecuador (92 species of mollusks, 31 of crustaceans, and 17 of echinoderms) occur in the intertidal area (Fig. 26) (Mair et al. 2002).

The marine vertebrates of Ecuador have also been studied. According to the FAO (1993), there are 26 mammalian species of which dolphins with 13 species are the most abundant followed by whales with 6 species (Fig. 27) (Fischer et al. 1995).

The marine birds which populate the Galapagos Islands are the same as those on the continent. Harris (1982) reported 18 species of marine birds on the islands. Based on the number of nests, it is considered that Nannopterum harrissi is one of those more abundant (Fig. 28).

The meiobenthic fauna is known mainly only at the phylum level, but some groups to classes. Cruz (in press) reports 19 groups of meiobenthos from the Gulf of Guayaquil. The only paper about free-living nematodes from a sand beach is also currently in press (Figs. 29, 30).

\section{e. ICHTHyOPLANKTON (FISH LARVAE)}

There are about 43 families of fish larvae (Fig. 31 ) with 60 species identified for Ecuador (Fig. 32) (Luzuriaga de Cruz 1998).

It must be pointed out that these results are incomplete as they represent only 8 of the 31 zoological phyla. Nevertheless, in themselves, they also are a contribution to the knowledge of the marine biodiversity of Ecuador. 


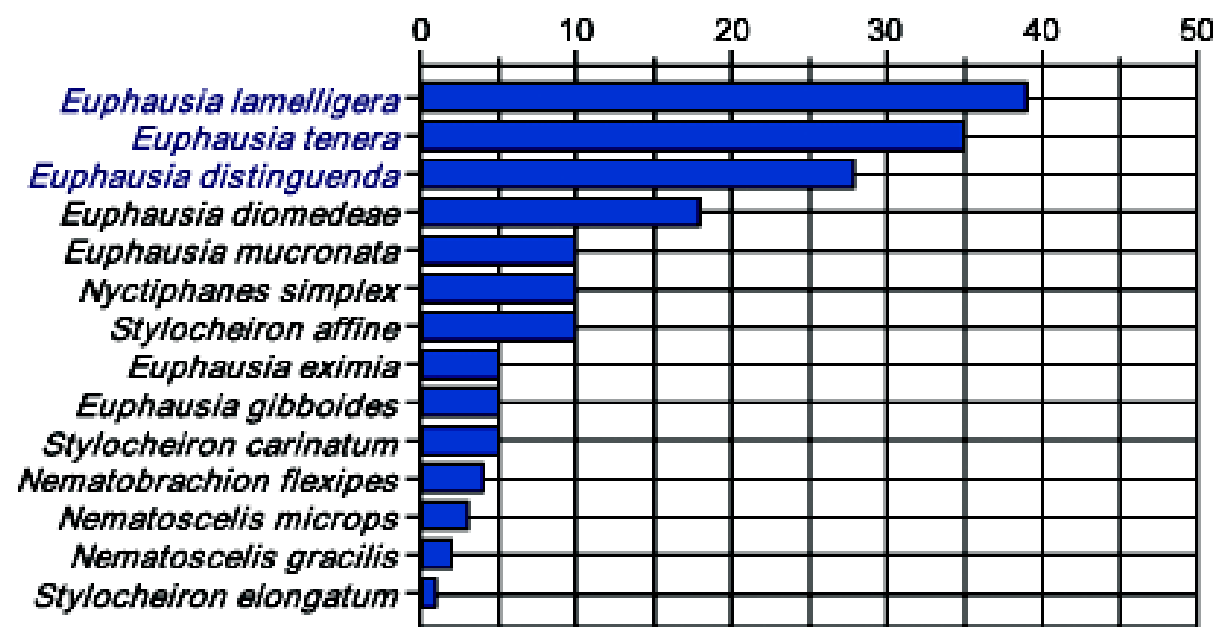

FIGURE 16. Relative abundance of 14 species of Euphausiacea from the Equatorian Pacific (Cornejo de González 1976).

FIGURA 16. La abundancia relativa de 14 especies de Euphausiacea del Pacífico ecuatoriano. (Cornejo de González 1976).

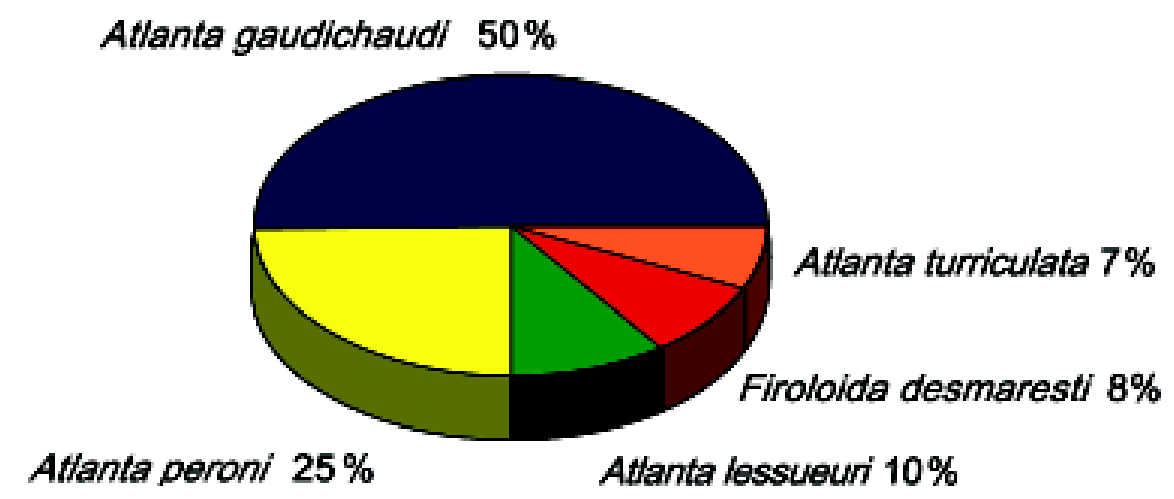

FIGURE 17. Relative abundance of the planktonic Heteropoda (5 spp.), from the Equatorian Pacific (Cruz 1996).

FIGURA 17. La abundancia relativa del plancton Heterópoda (5 spp.) del Pacífico ecuatoriano (Cruz 1996). 


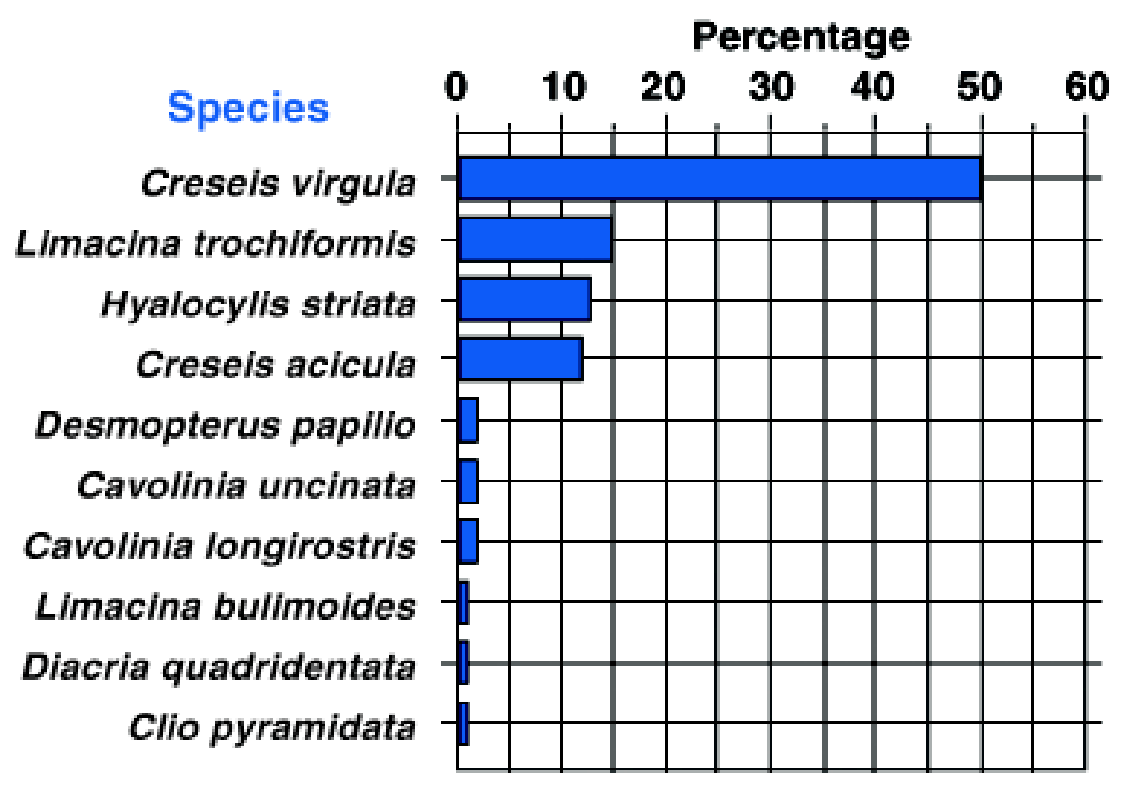

FIGURE 18. Relative abundance of the Thecosomates Pteropoda from the Equatorian Pacific (Cruz 1996).

FIgURA 18. La abundancia relativa de los Pteropoda Thecosomates del Pacífico ecuatoriano (Cruz 1996).

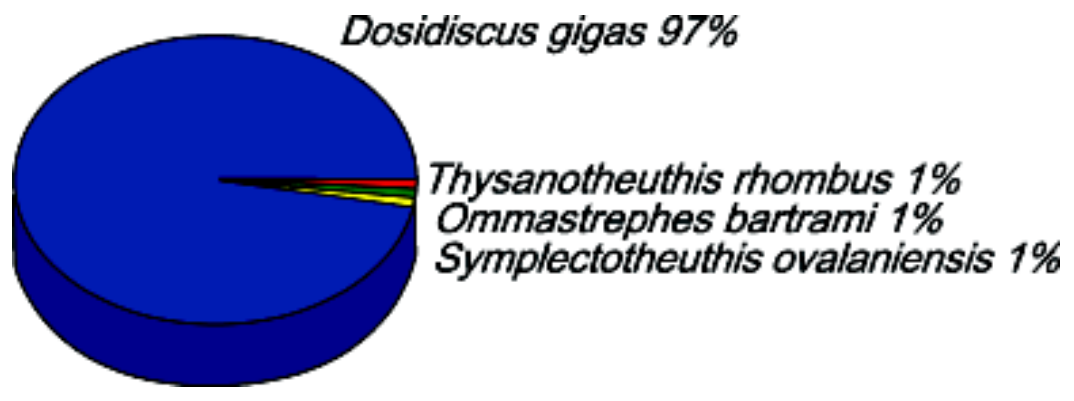

Figure 19. Dosidicus gigas d'Orbygni 1835, is the most abundant species in the Equatorian waters (Pacheco et al. 1994).

FIGURA 19. Dosidicus gigas d'Orbygni 1835, es la especie más abundante en las aguas el cuatorianas (Pacheco et al. 1994). 


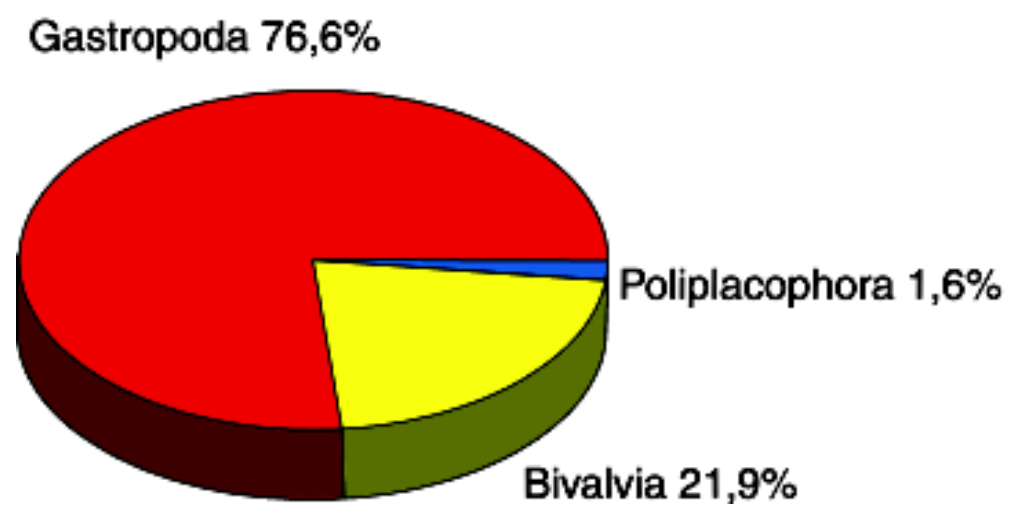

FIGURE 20. Hickman \& Finet (1998) report 256 species of marine mollusks (Gastropoda: 196 spp., Bivalvia: 56 spp., and Polyplacophora: 4 spp.), from Galapagos Island, Ecuador.

FIGURA 20. Hickman \& Finet (1998) reportaron 256 especies de moluscos marinos (Gastropoda: 196 spp., Bivalvia: 56 spp. y Polyplacophora: 4 spp.) de las islas Galápagos, Ecuador.

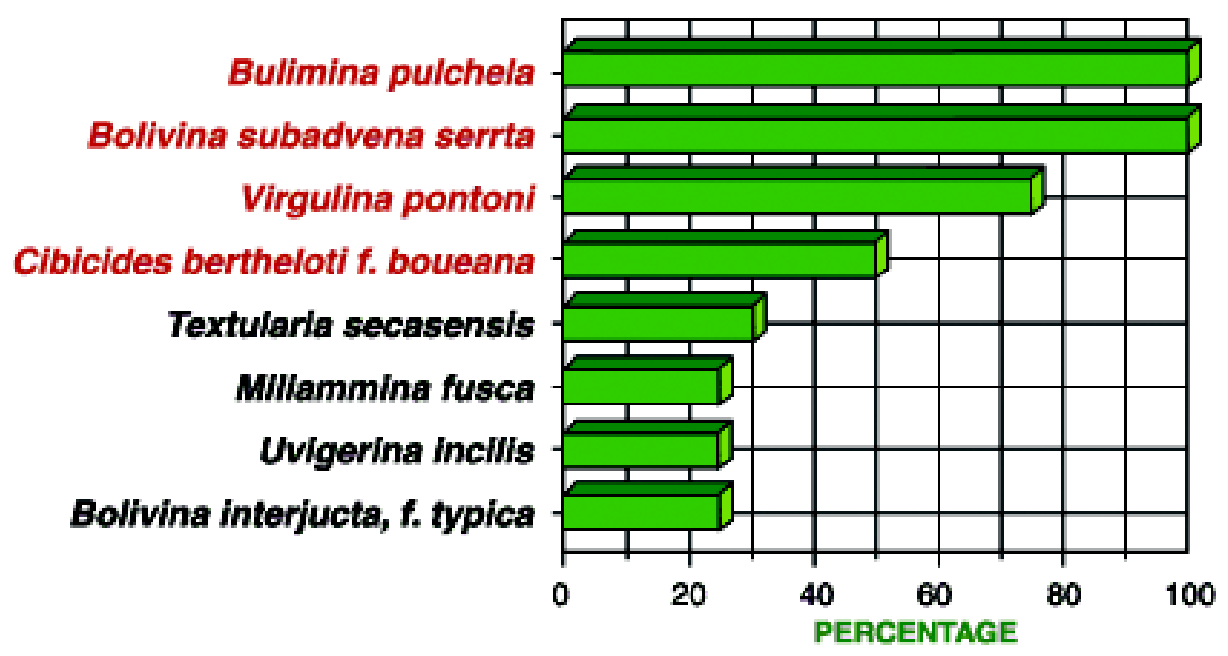

FIGURE 21. The eight most common and abundant species of 147 reported from the continental shelf of Ecuador (Gualancañay 1975).

FIGURA 21. Las ocho especies más comunes de los 147 reportados de la plataforma continental de Ecuador (Gualancañay 1975). 


\section{f. DEMERSAL AND BENTHIC FISH SPECIES}

The 479 recorded species are grouped in 4 phyla (Chordata, Arthropoda, Mollusca, and Echinodermata). These comprise 258 genera, 143 families, and 41 orders (Table 2). The most important commercial species are 'corvina' (Cynoscion sp.), 'perela' (Paralabrax sp.), 'camotillo' (Diplectrum spp.), 'lenguado' (Paralichthyies spp.), and shrimp (Litopenaeus spp.).

The phylum (Chordata) represented by fish is the most diverse coastal water group with 270 species included in 142 genera, 63 families, and 22 orders, the order Perciformes being the best represented with 143 species.

The Crustaceans are represented by 85 species belonging to 34 genera, 25 families, and 3 orders. The most diverse order is Decapoda with 77 species. The mollusks constitute, after the fish, the group with the highest diversity with 111 species, 71 genera, 43 families, 8 orders with the Gastropoda (Mesogastropoda and Neogastropoda) followed by the order Veneroida being the most numerous.

The Echinodermata group has 11 genera, 11 families, and 8 orders (Phanerozonia, Ophiurae, Euryalae, Cidareoidea, Aulodonta, Camarodonta, Aspidochirota, Dendrochirota), and 13 species.

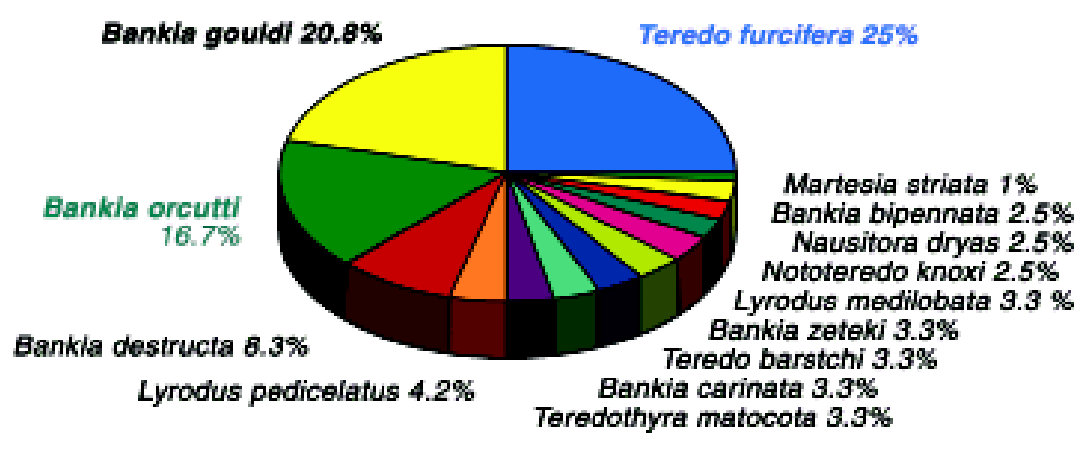

FIGURE 22. Relative abundance of 14 species of wood boring mollusks from the Equatorian Pacific (Cruz 1992).

Figura 22. La abundancia relativa de las 14 especies de moluscos del Pacífico ecuatoriano (Cruz 1992).

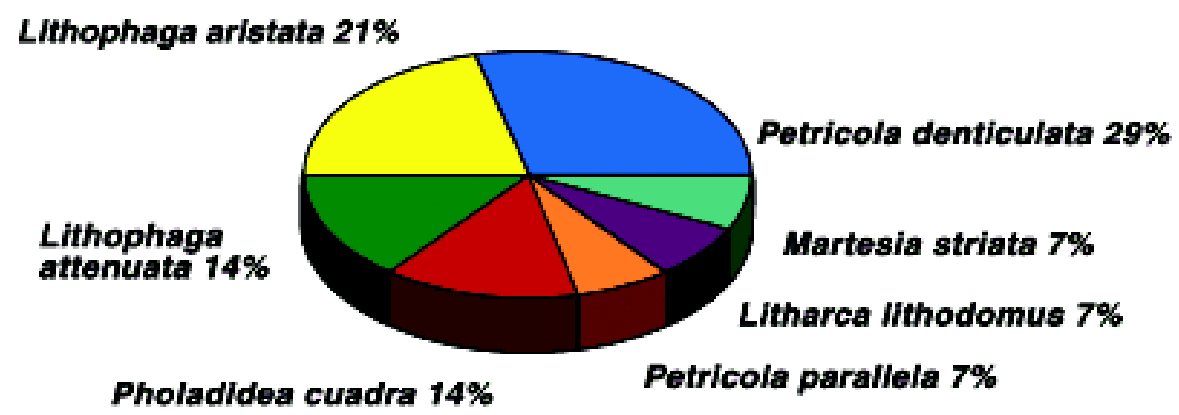

FiguRE 23. Frequency of the rock boring mollusks, from the intertidal zone of the Equatorian Pacific (Cruz, M. internal report 2002).

FIGURA 23. La frecuencia de los moluscos de la zona intermareal del Pacífico ecuatoriano. (Cruz, M. reporte interno 2002) 


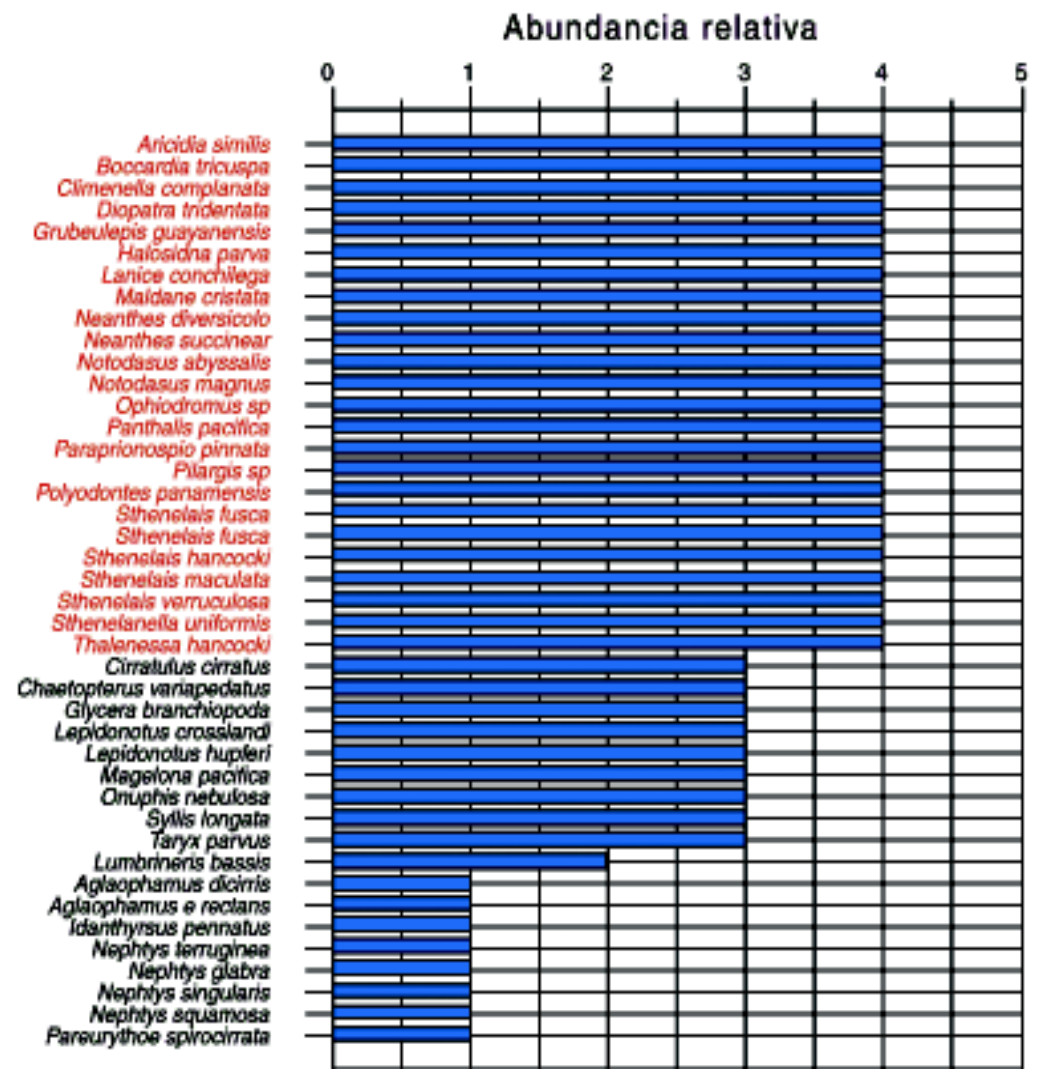

FIGURE 24. Relative abundance of 42 species of benthonic polichaetes (24 Errantia and 18 Sedentaria), from the Equatorian shelf (Villamar 1983b).

Figura 24. La abundancia relativa de las 42 especies de polichaetes (24 Errantia y 18 Sedentaria) de la plataforma ecuatoriana (Villamar 1983b).

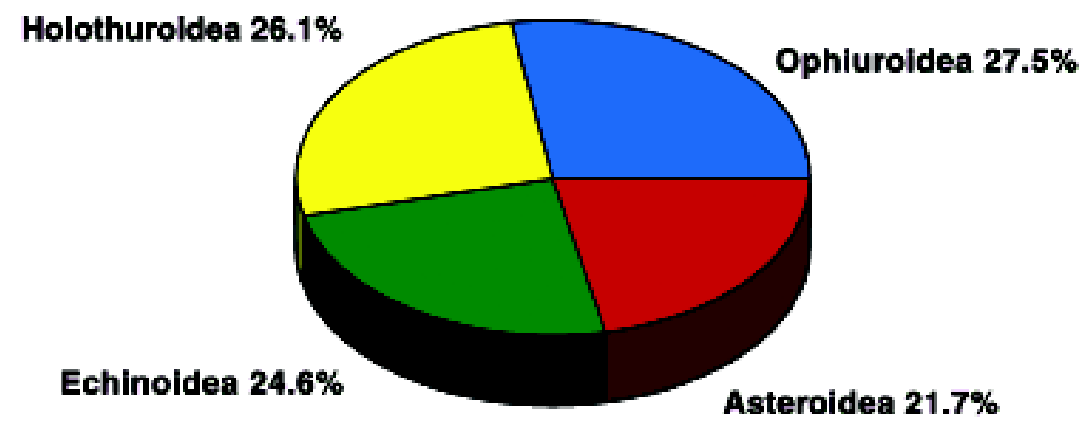

FIGURE 25. Hickman (1998) reported 69 species of Echinodermata (Ophiuroidea 19 sp., Holothuroidea 18 sp., Echinoidea 17 sp., and Asteroidea 15 sp.) from Galapagos Islands, Ecuador.

FIGURA 25. Hickman (1998) reportó 69 especies de Echinodermata (Ophiuroidea 19 sp., Holothuroidea 18 sp., Echinoidea 17 sp. y Asteroidea 15 sp.) de las Islas Galápagos, Ecuador. 


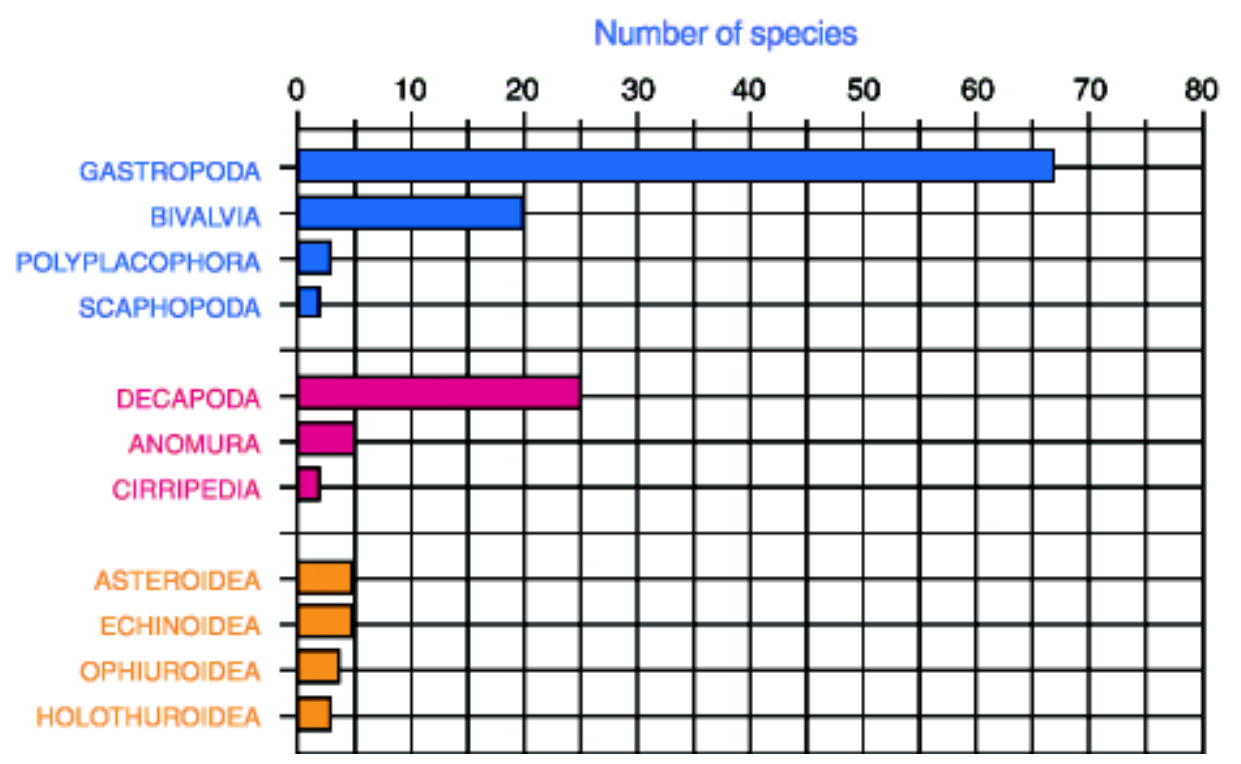

FIGURE 26. Mair et al (2002) report 140 species of macroinvertebrates: mollusks (92 spp.), crustaceans (31 spp.), and echinoderms (17 spp.) for the Equatorian intertidal zone.

FIGURA 26. Mair et al (2002) reportaron 140 especies de macroinvertebrados: moluscos (92 spp.), crustáceos (31 spp.) y echinodermos (17 spp.) para la zona intermareal ecuatoriana.

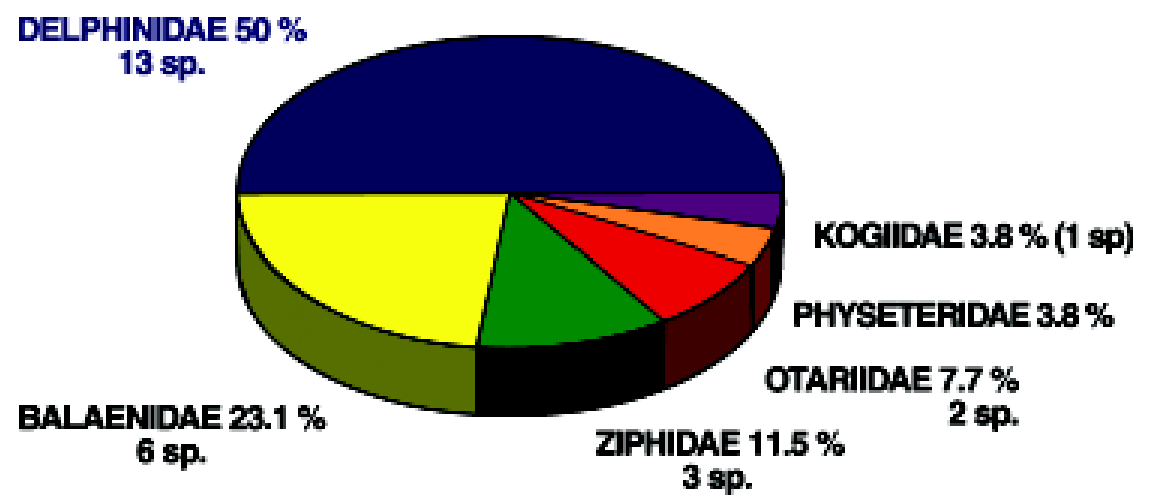

FigURE 27. According to FAO (1993), 26 species of marine mammals have been reported for the Equatorian Pacific.

Figura 27. Según la FAO (1993), hay 26 especies de mamíferos marinos reportados para el Pacífico ecuatoriano. 


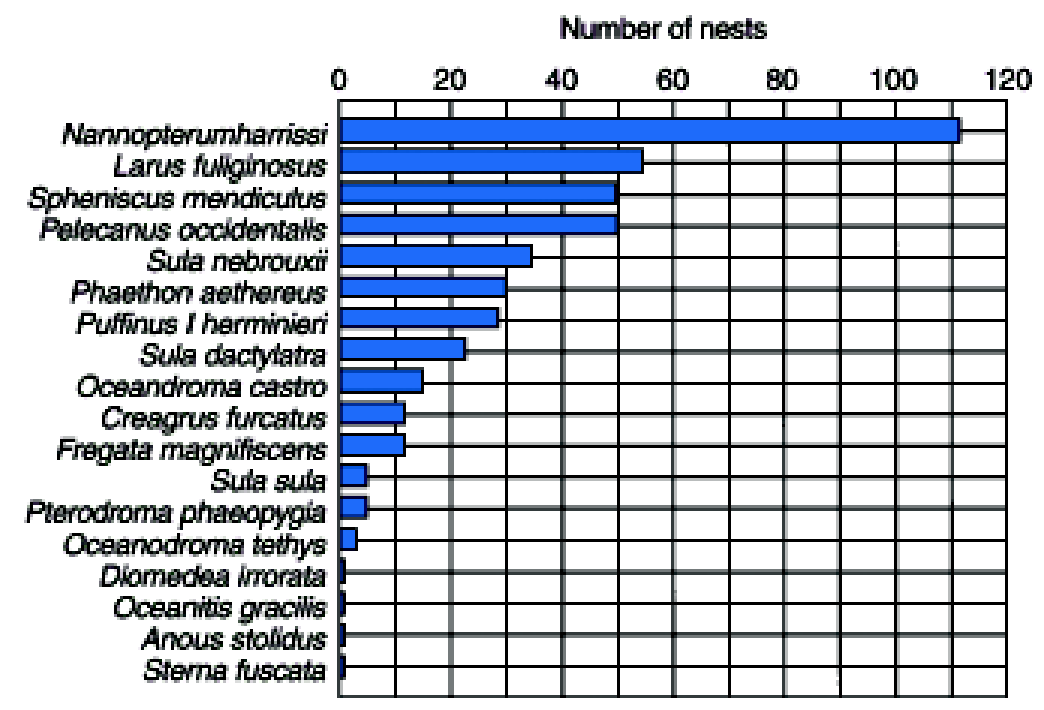

FIGURE 28. Relative abundance of 18 species of marine birds from the Galapagos Islands (Harris 1982).

FIGURA 28. La abundancia relativa de 18 especies de aves marinas de las Islas Galápagos (Harris 1982).

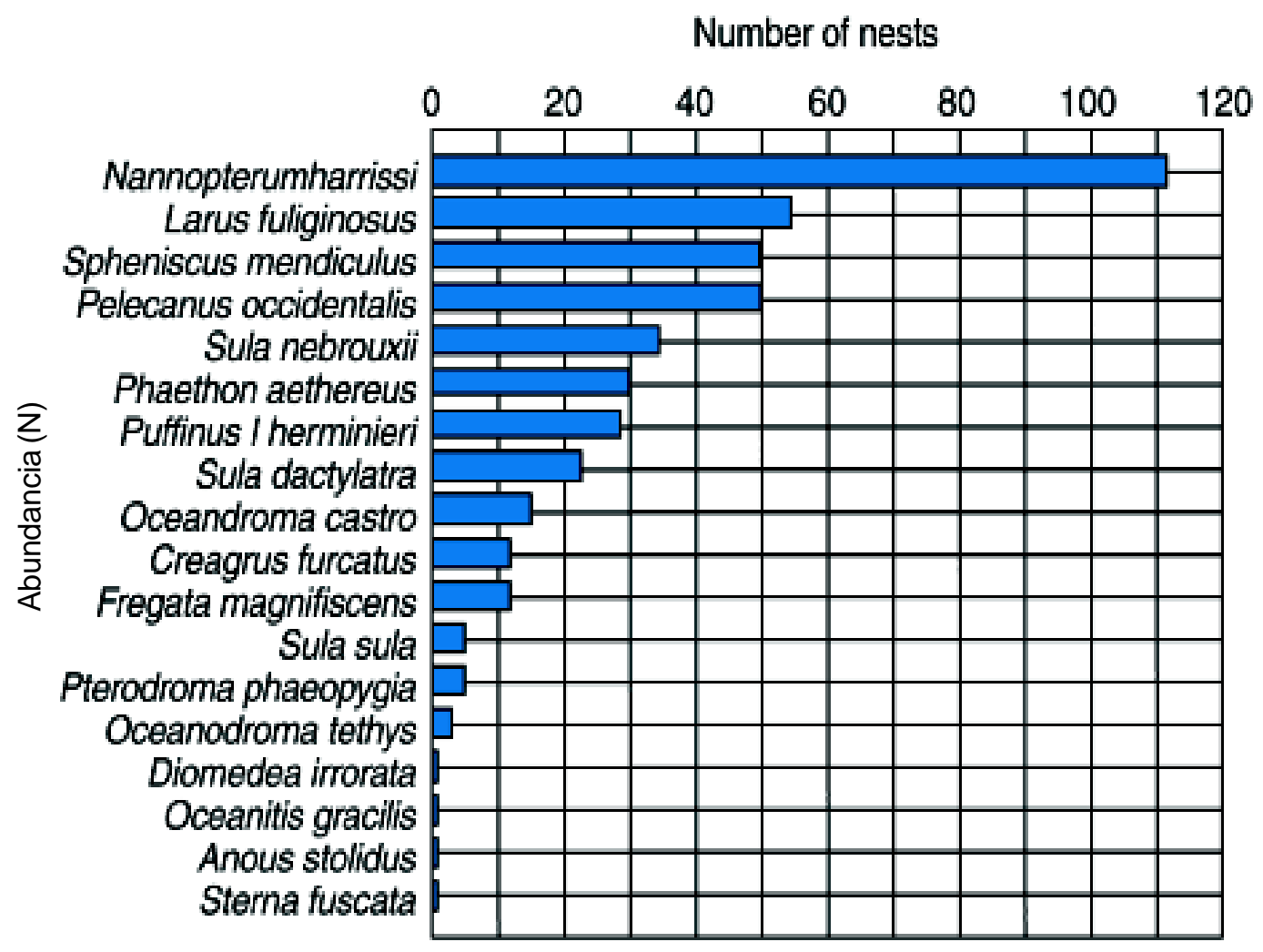

FIGURE 29. Nineteen (19) groups of meiobenthic organisms were found in the Gulf of Guayaquil, during April 1997 (Cruz 2003).

FIGURA 29. En abril de 1997 se encontraron 19 grupos de organismos meiobénticos en el Golfo de Guayaquil (Cruz 2003). 


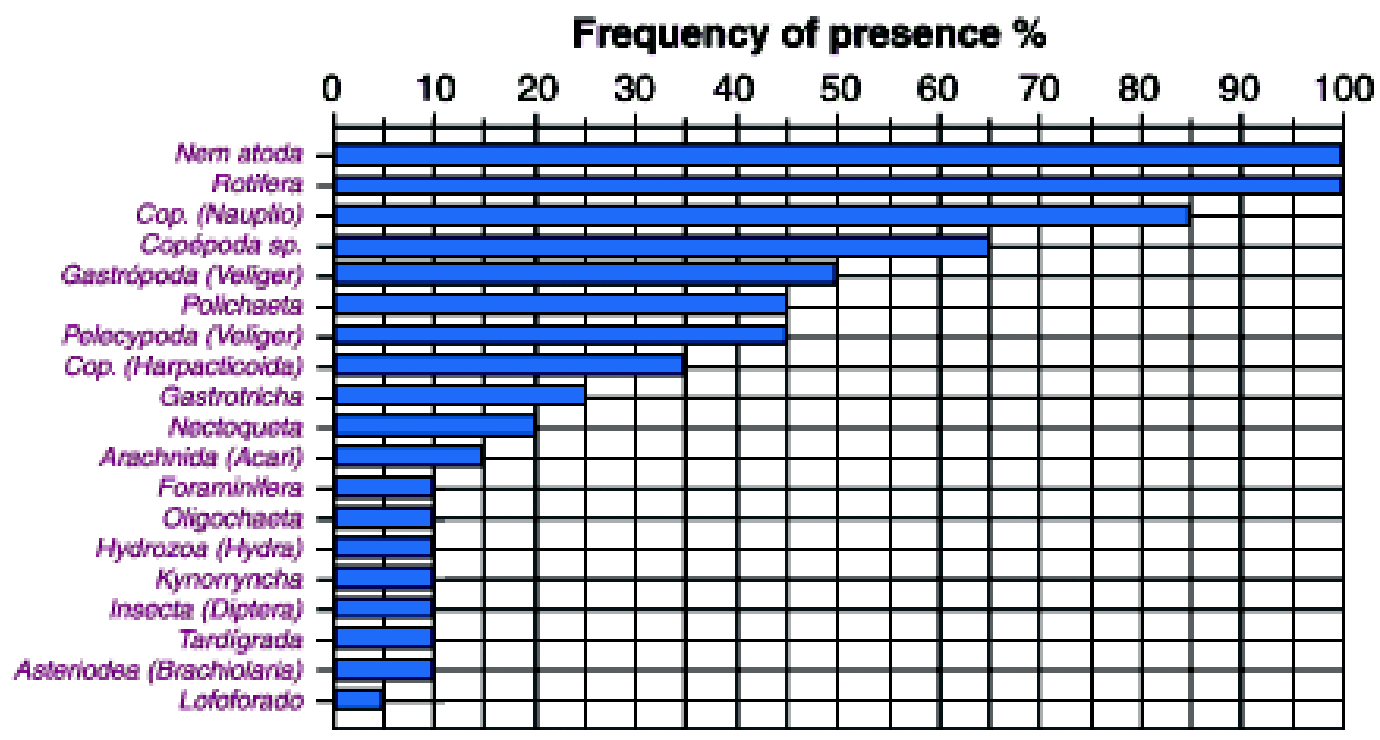

FIGURE 30. The free-living nematodes are the most abundant among 19 groups of meiobenthic invertebrates from the Gulf of Guayaquil (Cruz 1998, 2002).

FIGURA 30. Los nematodos independientes son los más abundantes de los 19 grupos de invertebrados meiobénticos en el Golfo de Guayaquil (Cruz 1998, 2002).

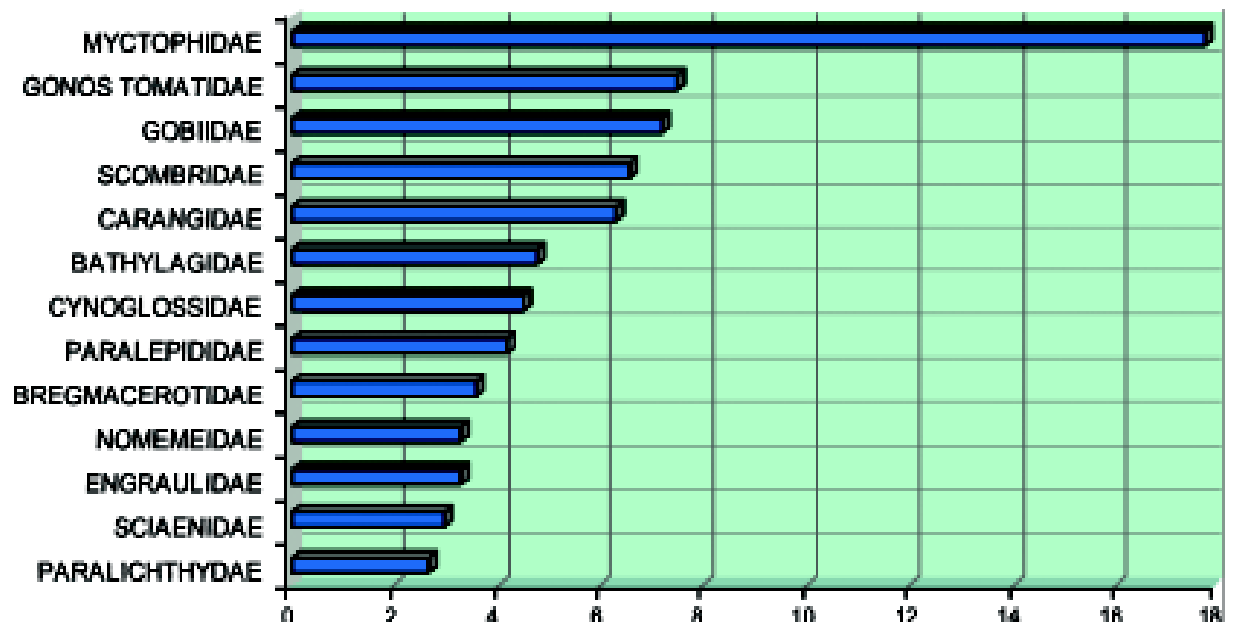

FIGURE 31. The most frequent families of fish larvae in the Equatorian Pacific, during 1998 (Luzuriaga de Cruz \& Ortega 1998).

FiguRA 31. Las familias más frecuentes de larvas de peces en el Pacífico ecuatoriano durante 1998 (Luzuriaga de Cruz \& Ortega 1998). 


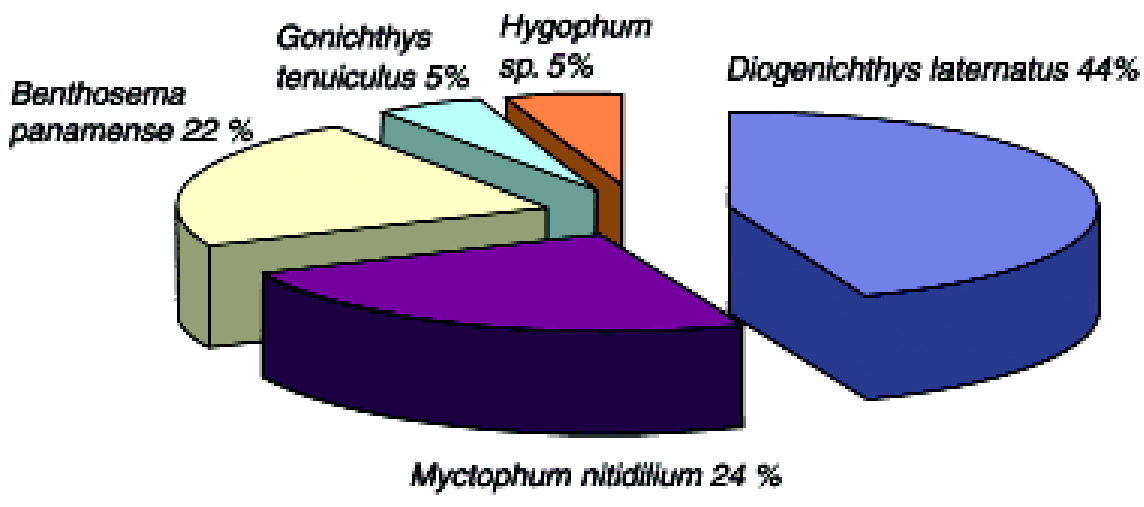

FIGURE 32. Relative abundance of the principal species of fish larvae of the family Myctophidae in the Equatorian oceanic waters (Luzuriaga de Cruz \& Ortega 1998).

FiguRA 32. La abundancia relativa de las especies principales de larvas de peces de la familia Myctophidae en las aguas oceánicas ecuatorianas (Luzuriaga de Cruz \& Ortega 1998).

The demersal fish group, which belongs to a variety of families, is made up of a diversity of species. The most important are 'corvina de roca', Brotula clarkae (Brotulidae); 'cherna', Mycteroperca xenarcha (Serranidae); 'perela', Paralabrax callaensis (Serranidae); bass, Centropomus sp. (Centropomidae); corvina plateda, Cynoscion sp. (Sciaenidae); 'pargo', Lutjanus sp. (Lutjanidae) and 'huayaipe', Seriola spp. (Carangidae).

Demersal fishes occupy second place in the annual landings of the artisanal fishing fleet. They are also caught by the semi-industrial white fisheries. Marine fish resources, both from the sea and those derived from fish farming, represent major economic assets for Ecuador.

The marine shrimps Litopenaeus vannamei, $L$. stylirrostris, L. occidentalis, and Farfante californiensis are also important to the economy of the country. They were even more so during the 1970s and 1980s. However, catches are decreasing due to previous over-fishing as well as the influence of climatic conditions. Serious over-exploitation of stocks and the lack of appropriate regulations for their management and to ensure their sustainability have been the negative elements that have caused the decrease in the size of the shrimp populations. They now need to be allowed to recover and return to the original economic fishing levels.

A solution to this complex problem arose with the great increase in shrimp cultivation. However, the lack of application of concepts of sustainable ma- nagement of the resource has, over time, caused the appearance of a series of pathogens that have diminished shrimp production by $70 \%$.

Catches of the lobsters Panulirus gracilis and $P$. penicillatus, which have been commercially exploited since the 1960s, have similarly suffered. They constituted an important resource that brought foreign currencies to the country, with $100,319 \mathrm{~kg}$ being exported in 1985 (DGP, 1990). According to Correa et al. (1994), the problem has arisen from the capturing of animals of less than $25 \mathrm{~cm}$ in length. The establishment of a protocol, actively targeted at the fishermen and merchants, about the importance of respecting the restrictive measures in the capture of this crustacean is now required. At the moment, the Undersecretary of Fisheries, the General Council of Fisheries and the National Institute of Fisheries are making efforts to implement appropriate policies for the correct exploitation of this resource.

Other important resources are the red swamp crab Ucides occidentalis, the 'pangora' Menipes frontalis and the dog crab Xantipes sp., which are captured by local artisanal fishermen. The first of these is caught in large numbers but they are mostly consumed locally. In the last few years, there has been a general decrease in the capture of this resource. This is related directly to the opening-up of the swamp to build shrimp pools, thereby reducing the areas available for catching the crabs (Barcia \& Marriot 1993). 
Finally, the commercial exploitation of a new resource has begun, namely the harvesting of barnacles, though studies of its market potential and the biological and ecological implications are necessary. Additionally, there is the need for the training of local fishermen with specialized techni-ques so that they can carry out a sustainable extraction of this resource.

At the present time, 23 species of mollusks are harvested artisanally. Very little has been published about this important group of resources. Most of these mollusks inhabit mangroves and other ecosystems distributed along the Equatorian continental coast. Species such as Anadara tuberculosa, A. similis, and A. grandis ('pata de mula' or mule foot) constitute true alternatives for the diversification of aquacultural activities. This is important for the economy of the artisanal communities as it will create employment opportunities. The government has taken measures to control and to preserve the distribution and abundance of these mollusks.

A species with great fishing potential is the giant squid Dosidicus gigas which, at present, is caught mainly by 'poteras' on board. A new technique could be designed for the increased extraction of this cephalopod.

In Ecuador, two echinoderm species are now being considered as potential alternatives for the artisanal fisheries; the sea cucumber Isostichopus fuscus and the sea urchin Tripneustes depressus. However, very little is known about their ecology and reproductive biology, so that their high commercial value together with the lack of upgraded fishing legislation for managing these fisheries resources have put at risk not only the sea cucumber and sea urchin populations but also the fragile ecosystem to which they belong. A sea cucumber fishery has been developed during the last 10 years in the Galapagos Islands even though the National Park has tried to maintain a regulated fishery. There is still a lot of work to do in spreading education about fisheries to both the fishermen and the legislators.

Information about marine biodiversity in the Galapagos Islands is still insufficient. So far, the scientific studies have been limited to basic research and the taxonomy of the biota. No explanatory work and correlations have been attempted. It has recently been calculated that between 10 and $20 \%$ of the species there are endemic (Hurtado et al. 2000) but, the total number of fish species reported in the Galapagos region had increased to 444 from 306, the number in an earlier inventory of fish of the Galapagos Islands (Grove \& Lavenberg 1996). This would indicate that endemism could have diminished from $16.7 \%$ to $9.4 \%$.

Additionally, the new inventory gave the number of recorded species of endemic fish as 41 , that is 3 fewer than in the inventory of McCosker \& Rosenblatt (1984). Four new species of endemic fish were discovered, however; these have yet to be given scientific names.

\section{MAJOR IMPACTS ON MARINE AND COASTAL ECOSYSTEMS}

Impacts can be grouped into six main categories:

- Fisheries operations

- Global climate change

- Alterations of physical habitat

- Invasions of exotic species

- Contamination

- Overpopulation of the Equatorian coastal zone and Galapagos Islands.

Industrial bottom fishing disturbs both benthic organisms and damages their habitat, the seabed. There are also concerns that those fisheries stocks are being affected by the over-fishing of commercial species and the development of the coast that may permanently damage mangrove and reef ecosystems on which the fisheries rely. Over-fishing may also have a destructive physical impact on the intertidal zone, and can affect the population levels of nontargeted species through incidental catches, the latter problem being of particular significance for sea turtles, sharks and seabirds.

Periodic changes in climate are the primary threat to coral reefs on a global scale. The increase in seasurface temperature associated with the major El Niño event in 1982-1983 resulted in extensive coral bleaching and mortality in the Galapagos Islands; mortality levels of greater than $90 \%$ left some reefs almost bared of corals and there were signs of major shifts in the population structures.

\section{THE UNKNOWN}

In Ecuador, the study of marine biodiversity has not, in general terms, been a high priority for the 
Equatorian authorities, except in the case of a few commercial groups. Little attention has been paid to the economic and social potential of the biotic resources in terms of local, national and regional development.

Related to studies on plankton, little information is available about it in the estuarine areas. Groups such as the unarmored dinoflagellates need to be investigated in view of their toxicity and very little is known about the rotifer and free-living marine nematodes. There is also a lack of data of groups with high biodiversities like the copepods, amphipods and isopods. The dynamics of the phytoplankton and zooplankton populations also require study, as do the DNA contents of the main planktonic species to determine changes or mutations caused by radiation or contamination of the ecosystem.

The succession of benthic invertebrate populations in rocky and sandy substrates of the Equatorian coast is unknown and there is a lack of information on the antozoans that includes the corals, anemones that characterize the reefs. Among the annelids, only the benthic polychaetes have been described and little is known about their planktonic forms and of the Oligochaeta and Hirudinea classes.

In Ecuador, the meiofauna have not been identified at the species level while those that exist in the Gulf of Guayaquil are known only at the phylum level. Data on marine nematodes in the intertidal area exist but have not yet been published.

There are 60 known species of ichthyoplankton but further sampling of all the environments including the Galapagos Islands will probably reveal more.

There is a need to study the biodiversity of benthic fish and their distribution as well as the zoning of commercial benthic species. The main species of fish, mollusks, crustaceans, and echinoderms are well known but the remaining phyla, especially those that do not have commercial importance, are unknown.

Groups such as the Radiolarians, Acantharians, and Thecamoebans, among others, are also unstudied.

No studies of the life cycles of species, including those of economic importance, have been done in Ecuador. The key life history traits of organisms need to be known in order to determine their capacity to respond to changes in their environment.

Research on larval development is important for the future, and studies of the meiobenthos present on the continental Equatorian coast and in the Galapagos Islands should be continued.

The unknown species of the following phyla need to be identified: Porifera, Cnidaria, Ctenophora, Platyhelminthes, Nemertina, Acanthocephala, Gastrotrichs, Nematoda, Nematomorpha, Loricifera, Kinorhyncha, Priapulids, Sipunculida, Equiurida, Tardigrades, Phoronida, Brachiopoda, Briozoa or Ectoprocta, Hemichordata, Arthropods (Chelicerata), Crustacea (with the exception of the Decapods), and Euphausiids).

Scientists should identify priority areas and taxonomic groups of interest for completing biological inventories. They should encourage the development of a geographic information system for detecting areas of high diversity, and design species/area graphics for predicting extinction patterns and aiding the formulation of policies for conservation and economic development. Carefully chosen study sites for long-term research and monitoring changes in biodiversity over a decadal time scale need to be established.

\section{DISCUSSION AND PERSPECTIVES}

In the tropical seas off Ecuador, biodiversity can be very high. At a single station, a phytoplankton expert might deal with 100 species of diatoms, dinoflagellates, coccolithophorids, and flagellates, especially during the El Niño events, when the species diversity of groups like dinoflagellates increases.

In Equatorian tropical coastal waters, the separation of invertebrate fauna in samples from scarcely or unpolluted areas, into recognizable species are often hampered by the huge numbers of undescribed species present. Despite the huge variety of marine biota in Ecuador, the information about it is limited and varies greatly among taxa and among regions. Taxonomic knowledge is poorest in those areas possibly harboring the highest levels of biodiversity. There are few checklists for many taxonomic groups. The use of geographical information systems is limited by the lack of reliable data on species distributions and climate. No studies have focused on the relationship between climate change and biodiversity. The taxonomic information available is largely at the most basic descriptive level. There is little information about the phylogeny of species, 
their geographical distributions and abundances, and related biological and ecological aspects.

Issues such as environmental assessments of the impacts of industrial activities in the coastal zone and pollution from land-based sources require taxonomic and ecological data for the biota. Surprisingly, these studies are carried out at the level of major groups, frequently without attention to groups considered unimportant and the results have little value for ecological research or the future evaluation of climatic changes.

Activities, such as aquaculture and environmental studies, require basic knowledge of the species diversity present in the environment. Although more administrative issues are being incorporated into the management of the environment, less biological and taxonomical research is being carried out.

Additionally, samples of plankton, invertebrates, and fish in the Reference Collections are not being well maintained. There is a need to create a GIS-Database not only for biological but also for oceanographic data.

Viable population sizes should be determined for key groups of taxa and species and the latter should be monitored throughout their distribution for changes in population size. Records of viable fishegg numbers must be determined in potentially polluted areas since abnormal embryos could be an important part of the biomass.

There are frequently reports of the lack of biological information about unusual events in the marine environment. Among these are red tides, blooms of blue-green algae or cyanobacteria, the proliferation of luminescent bacteria, mass mortalities of fish, turtles and marine mammals, the defoliation of mangrove trees, the proliferation of marine fungi in the estuarine zones, etc. One of the major difficulties in dealing with these events is the absence of basic information about the species involved. Sometimes, even simple questions cannot be answered and this can generate conflicts between institutions and scientists.

Reliable assessments of the productivity of the ocean, of the interrelationships between organisms, or of the ecology of coastal waters in relation to climatic variability, monitoring, and environmental impacts cannot be made if high grade taxonomical data are not available.

The training of new specialists is necessary. Despite the high cost of cruises and biological sampling programs, no more than 5 to 10 people in each institute are available to do taxonomical research. Usually, the same person who takes the sample processes it, then analyzes and interprets the data, and writes the report. Very often, the same scientist has to examine samples from coastal areas and the open ocean. Most of the few taxonomical experts in Ecuador are now nearing retirement. New personnel are needed in a number of areas, especially taxo-nomy, the use of geographical information systems, population biology, regional planning, and economics and sociology.

The national and local research councils practically ignore projects involving taxonomy and, without grants to do the research, no university is likely to run courses in systematics. An exception has been the Faculty of Natural Science in the School of Biology at the University of Guayaquil where, since the early 1970s, about 20 people have been studying the taxonomy of plankton, benthos, invertebrates, and fish. This group is now approaching retirement, however, and very few new scientists are taking over.

In Ecuador, there are more than 15 post-graduate courses in environmental issues. Most of them have backgrounds in disciplines distinct from biology and sometimes appear to be prejudiced against taxonomy. Multidisciplinary research in environmental research relevant to sustainable development must be promoted with more people involved and the integration of libraries, universities, and non-university laboratories.

International collaboration to reinforce research in taxonomy and biodiversity using information technology is required in Ecuador in order to build up a marine biodiversity database. The use of the Linnaeus II program for this purpose is recommended; it will be a necessary step in maintaining intellectual property rights on taxonomic information.

Biodiversity must be considered as an important part of the genetic wealth of a country. Conserving it might involve creating banks of germoplasm, preserving the knowledge of indigenous people as to the value of certain species, identifying key species for biodiversity studies, and other measures, including habitat protection.

The description and classification of species are fundamental to biology. Unless we can communicate precisely and unambiguously about the organisms 
that are directly or indirectly part of everyday life, our ability to feed and care for ourselves and understand the world in which we live is seriously impaired.

\section{AKNOWLEDGMENTS}

The authors would like to thank several people and institutions that helped us to gather the information presented in this paper:

CPNV-EM Byron San Miguel and Captain Jorge Cardenas, respectively Director and Head of the Marine Sciences Department of the Oceanographic Institute of the Navy (INOCAR), as well as our colleagues biologist in that laboratory.

We are also grateful to Dr. Franklin Ormaza González, Director of the National Institute of Fisheries (INP), and to the researchers at the Fishing Resources Department, as well as to our assistants, Lili Sandoval and María Peña.

And finally, we offer our sincere thanks to Ing. José Cuenca, Dean of the Natural Sciences Faculty of the University of Guayaquil.

\section{REFERENCES}

Arriaga, L. 1997. El impacto del evento El Niño en la pesca y acuicultura. Programa de Pesca VECEP/ Instituto Nacional de Pesca.

Arriaga, L. 1999a. Informe sobre el evento El Niño 1997-1998, y sus efectos en la pesca. Instituto Nacional de Pesca. Boletín Científico y Técnico.

Arriaga, L. 1999b. Informe sobre el evento La Niña en la pesca. Programa de Pesca VECEP/Instituto Nacional de Pesca.

Barcia, M. \& X. MARRIot. 1993. Estimación del número de cangrejos rojos, Ucides occidentalis (Ortmann), en un remanente de manglar del estuario del río Chone. Informe técnico interno. INP/PMRC/ Universidad de Guayaquil.

BARRAGÁN, J. 1986. Informe sobre el cangrejo de manglar Ucides occidentalis Ortmann y la posibilidad de implementar una veda para su captura. Informe interno. INP.

Brusca, R. 1973. A Handbook to the Common Intertidal Invertebrates of the Gulf of California. University of Arizona.

Chalén, X. \& J. Correa. 2001. Crucero acústico para la evaluación de recursos pesqueros pelágicos en el Golfo de Guayaquil, febrero 2001. Instituto Nacional de Pesca (En prensa).

Chalén, X \& L. Sandoval. 2002. Variabilidad espacial de los recursos demersales del Golfo de Gua- yaquil. Tesis de Grado para obtener el título de Biólogo. Escuela de Biología, Facultad de Ciencias Naturales, Universidad de Guayaquil: $132 \mathrm{pp}$.

Chirichigno, N. 1970. Lista de crustáceos del Perú (Decápoda y Stomatopoda ) con datos de su distribución geográfica. Callao, Perú, Inst. Mar del Perú. Inf. $\mathrm{N}^{\circ} 35$.

Chirichigno, N. 1998. Claves para identificar los peces marinos del Perú. (Segunda edición). Instituto del Mar del Perú. Publicación especial. Callao, Perú.

Citron, G. 1981. El manglar en la costa ecuatoriana. Hoja de Documentación. Departamento de Recursos Naturales: 37.

Citron, G., A.E. Lugo, D.J. Pool, \& G. Morris. 1978. Mangroves of arid environments in Puerto Rico and adjacent islands. Biotropica 10:110-121.

Совo, M. \& S. Massay. 1969. Lista de peces marinos del Ecuador. Bol. Cient. Téc. Instituto Nacional de Pesca. Guayaquil, Ecuador. Vol. II, No 1.

Cornejo de González, M. 1976. Estudio preliminar de los Eufáusidos en el mar ecuatoriano. IOA.- CMBIO - 11. pp. 1-46.

Correa, J. 1993. Crustáceos de mayor importancia comercial en el Ecuador. En Catalogo de Peces, Crustáceos y Moluscos de mayor importancia comercial en Ecuador. Instituto Nacional de Pesca. Guayaquil, Ecuador: 71-112 pp.

Cruz, M. 1983a. Bivalvos del Golfo de Guayaquil. Acta Oceanográfica del Pacífico, 2(2): 735-819.

Cruz, M. 1983b. Presencia de Pterópodos Tecosomados en el Golfo de Guayaquil. Acta Oceanográfica del Pacífico, 2(1): 179-186.

Cruz, M. 1983c. Pterópodos y Heterópodos del Golfo de Guayaquil. Acta Oceanográfica del Pacífico 2(2): 569-587.

Cruz, M. 1987. Moluscos Bivalvos de la Plataforma Continental de Manabí. Ecuador. Acta Oceanográfica del Pacífico. 4(1):75-101.

Cruz M. 1992. Estudio de los Moluscos Incrustantes de Maderas en el Mar Ecuatoriano. Acta Oceanográfica del Pacífico. 7(1).

Cruz, M. 1992. Estado actual del Recurso Malacológico (Bivalvos y Gasterópodos) de la Zona Infralitoral del Golfo de Guayaquil. Acta Oceanográfica del Pacífico. Vol. 7(1).

Cruz, M. 1996a. Pterópodos Tecosomados y Heterópodos (Gasterópodos) como Bioin-dicadores del Evento "El Niño" 1992, en la estación fija "La Libertad", Ecuador. Acta Oceanográfica del Pacífico, 8 (1):51-66.

Cruz, M. 1996b. Contribución al conocimiento de los organismos perforadores de maderas en la isla Baltra, Archipiélago de Galápagos, Ecuador. Acta Oceanográfica del Pacífico. 8(1):74-85

Cruz, M. 1998. Estudio del meiobentos en el Golfo de Guayaquil (Río Guayas, Canal Cascajal y Estero Salado), Ecuador, en agosto de 1996. Acta Oceanográfica del Pacífico, 9(1):177-185. 
Cruz, M., G. Torres \& F. Villamar. 1987. Estudio de los moluscos Bivalvos perforadores de la madera Rhizophora harrisonii (Mangle) en la Costa Ecuatoriana. Acta Oceanográfica del Pacífico. 4(1):121-160. Presentado en las X Jornadas Nacionales de Biología. Guayaquil. Nov. 1986.

CuCAlon, E. 1983. Temperature, Salinity, and Waters mass distribution of Ecuador during an El Niño event in 1976. Revista Ciencia del Mar y Limnología. 2(1). Guayaquil. Sept. 1983.

Cucalon, E. 1984. Temperatura, salinidad y distribución de masas de agua en Ecuador durante el evento El Niño en 1976. Revista Ciencias del Mar y Limnología 2(1).

CuCALON, E. 1986. Variabilidad oceanográfica frente a la costa del Ecuador durante el período 19811986. CPPS, Boletín Erfen 19: 11-26.

FAO. 1982. Catálogo de especies marinas de interés económico o potencial para América Latina. Parte II: Pacífico Centro y Sur oriental. Programa de las Naciones Unidas para el desarrollo. Organización de las Naciones Unidas.

Fischer, W., F. KRUPp, W. SChNeIder, C. SOMMER, K. CARPENTER \& V. Niem. 1995. Guía FAO para la identificación de especies para los fines de la pesca. Pacífico centro oriental. Vol. II. Vertebrados - Parte I: 647-1200.

GABOR, N. 2002. Un océano inexplorado: las especies marinas del Ecuador. Revista Desafío, 3 (5).

Gualancañay, E. 1975. Foraminíferos bentónicos actuales de Ecuador. Provincia de Esmeraldas. Publicación INOCAR. CM-BIO-5.

GualanCAÑAY, E. 1983. Foraminiferos bentónicos del Golfo de Guayaquil. Acta Oceanográfica del Pacífico. 2 (2): 589-657.

Grove, J. \& R. Lavenberg. 1996. The fishes of the Galápagos Islands. Standford University Press.

HARris, M. 1982 Ecología comparativa de las aves marinas en el Archipiélago de Galápagos. Compendio de Ciencia en Galápagos. Estación Científica Charles Darwin. pp. 283 - 296.

Herrera, M., W. Revelo, T. De la Cuadra, P. Macías, D. Coello, O. Moya, E. Elías, D. Ortega \& H.Vicuña. 1998. Estimación de la Biomasa de los recursos demersales en la plataforma continental del Ecuador durante octubre de 1998. Bol. Cient. Téc. Instituto Nacional de Pesca. Guayaquil - Ecuador: 17 (3): 1 - 81.

Herrera, M., P. Solís-Coello, H. Vicuña, P. Macias, D. Coello, O. Moya, M. Luzuriaga \& E. Elías. 1999. Estimación de la Biomasa de los recursos demersales en la plataforma continental del Ecuador durante julio de 1999. Bol. Cient. Téc. Instituto Nacional de Pesca. Guayaquil, Ecuador: 18 (2): 1 - 112

HiCKMAN, C.P. JR. 1998. Guía de campo sobre estrellas de mar y otros equinodermos de Galápagos. Serie Vida Marina de Galápagos. Sugar Spring Press.

Hickman, C.P. JR. \& F. Yves.1999. Guía de campo de los
Moluscos Marinos de Galápagos. Serie Vida marina de Galápagos. Sugar Spring Press. pp. 1150.

Houvenaghel, G. \& N. Houvenaghel. 1982. Aspectos ecológicos de la zonificación de entremarea en las costas rocosas de las islas Galápagos. Compendio de ciencia en Galápagos. Public. Estac. Cient. Ch. Darwin. pp. 79-100.

Hurtado, M., G. Iturralde \& H. Suarez. 2000. Biodiversidad marina en el Ecuador continental. Informe final. Ministerio del Ambiente, Unión Mundial para la Conservación de la Naturaleza (IUCN) y EcoCiencia. (Documento inédito).

JefFerson, T.A., S. LeATHERWOOd, \& M.A. WebBer. 1993. FAO species identificatión guide. Marine mammals of the world. Rome, FAO. pp. 1-320, figs. 587.

JimenEz, R. 1983. Diatomeas y Silicoflagelados del fitoplancton del Golfo de Guayaquil. Acta Oceanográfica del Pacífico, 2(2): 193-281

KeEn, A.M. 1971. Sea Shell of tropical West America Marine mollusks from Baja California to Peru. 2da. ed. Stanford, C.A. Stanford University Press, xiv + 1-64 pp.

KeEn, A.M. 1971. Sea Shells of tropical West America. Marine Mollusks from Baja California to Perú. Stanford University.

Little, M. \& M. Herrera. 1991. Checklist and Catalogue of Recorded in the By- Catch of the Ecuadorian Shrimp Flett. Convenio Overseas development Administration of the UK. Government (ODA), Instituto Nacional de Pesca (INP), Guayaquil, Ecuador.

Luzuriaga DE Cruz, M. 1976. Foraminíferos planctónicos vivos en aguas superficiales ecuatorianas durante El Niño de 1972. Inst. Ocean. Armada, CM Bio 09. pp. 1-30.

Luzuriaga de Cruz, M. \& D. Ortega. 1998. Variaciones de las poblaciones del ictioplancton en el mar ecuatoriano, durante el evento El Niño 1997. 1998. Trabajo presentado en el Seminario Internacional del Fenómeno El Niño 1997-1998. CPPS. Guayaquil, Ecuador.

MaIr, J., E. Mora \& M. Cruz. 2002. Manual de campo de los invertebrados bentónicos marinos: Moluscos, Crustáceos y Equinodermos de la zona litoral ecuatoriana. Univ. de Guayaquil. pp. $1-105$.

Martínez, J. \& A. Madirolas. 1991. Areas de distribución y abundancia de los recursos demersales con énfasis en el recurso merluza (Merluccius gayi) en la plataforma continental del Ecuador. Boletín Científico Técnico. Instituto Nacional de Pesca. Guayaquil, Ecuador: $11(3): 1-37$.

Massay, SH. 1983. Revisión de la lista de peces marinos del Ecuador. Boletín Científico y Técnico. Vol. 6. $N^{\circ} 1$. Instituto Nacional de Pesca. Guayaquil, Ecuador.

McCosker, J.E. \& R.H. Rosenblatt. 1984. The inshore fish fauna of the Galápagos Islands. En: R. Perry (ed.) 
Galápagos, 1984. Key Environ. Ser. pp. 133-144.

McPAHLl, J. D. 1958. Clave de corvina (SCIAENIDAE) del Pacífico Oeste.

MÉNDEZ, M. 1980. Claves de Identificación y Distribución de los langostinos y camarones (Crustácea: Decapoda) de mar y Río de la Costa de Perú. Inst. Mar del Perú. Boletín. 5: 171.

Mora, E. 1990. Catálogo de Bivalvos Marinos del Ecuador. Bol. Cient. Téc. Instituto Nacional de Pesca.

Morris, P. 1966. Field Guide to Pacific Coast Shells including shells of Hawai and the Gulf of California. Peabody Museum of Natural History. Yale University. Second edition.

Naranjo, C. 2000. Contribución al estudio de los Quetognatos alrededor de las islas Galápagos. Acta Oceanográfica del Pacífico, INOCAR, Ecuador. 10 (1): 169-179.

NARANJo, C. 2002. Zooplancton en el estuario interior del Golfo de Guayaquil, durante mayo de 2001 (En prensa).

Olsson, A. 1961. Molusks of the tropical eastern Pacific, particularly from the southern half of the Panamic-Pacific faunal province (Panama to Peru), Panamic Pacific, Pelecypoda Paleontological Research Institution. Ithaca.

Pacheco, L., L. de Cajas, T. de la Cuadra \& R. Castro. 1994. Estudio sobre el calamar gigante (Dosidicus gigas) en aguas ecuatorianas (segunda etapa). Instituto Nacional de Pesca. pp. 1-36, figs. 52.

Pesantes, F. \& E. Pérez. 1982. Condiciones hidrográficas y químicas en el estuario del Golfo de Guayaquil. Revista de Ciencias del Mar. 1(2). Instituto Nacional de Pesca. Guayaquil, Ecuador.

Revelo, W. 1994. Areas de distribución y abundancia de los recursos demersales en la plataforma continental del Golfo de Guayaquil. INP. Bol. Cient. Téc. 12 (10): 1 - 23.

Revelo, W. 1995a. Distribución y abundancia de los recursos demersales en la plataforma continental del Ecuador, durante junio 1995. Boletín Científico y Técnico. Instituto Nacional de Pesca. Guayaquil-Ecuador: 13 (3): 1 - 47.

Revelo, W. 1995в. Distribución y abundancia de los recursos demersales en la plataforma continental del Ecuador, durante octubre de 1995. Boletín Científico y Técnico. Instituto Nacional de Pesca. Guayaquil-Ecuador: 14 (2): 1 - 39.

Revelo, W., J. GonZÁlez \& H. Vicuña. 1996. Evaluación de los recursos demersales en la plataforma continental del Ecuador durante mayo de 1996. Boletín Científico y Técnico. Instituto Nacional de Pesca. Guayaquil - Ecuador: 14 (5): 1-72.

Revelo W., M. Herrera., T. de la Cuadra., P. Macías., D. Ortega., M. Prado, \& H. Vicuña. 1998. Estimación de la Biomasa de los Recursos Demersales en la Plataforma Continental del Ecuador, durante julio de 1998 (02-16 de julio de 1998). Boletín Científico y Técnico. Instituto
Nacional de Pesca, Guayaquil-Ecuador. 1 Santos, J. 2002. Condiciones Oceanográficas actuales 25 de junio de 2002. Boletín informativo de la ESPOL. Centro de Investigaciones Científicas y Tecnológicas. 6 (4): 1-46.

SCHAEFFER-NOVELLI, Y. 1983. Inventario de los bio-rrecursos del manglar en la costa ecuatoriana. Informe Final. Misión de Consultoría sobre el Tema. 34.

Segura-Puertas, L. 1984. Morphology, Systematic and Zoogeography of medusae (Cnidarians: Hydrozoa and Scyphozoa) from the Eastern tropical Pacific. Bol. Cienc. del Mar y Limnol. Univ. Nal. Auton. México Publ. Esp. 8: 1-320.

SNEDAKer, S.C., J.C. Dickinson III, M.S. BROWN, \& E.J. LAHMANN. 1986. Shrimp pond siting and management alternatives in mangrove ecosystems in Ecuador. US Agency for International Development Report. Miami, Florida.

Stevenson, M. 1981. Variaciones estacionales en el Golfo de Guayaquil: un estuario tropical. Boletín Científico y Técnico. 4(1) Instituto Nacional de Pesca. Guayaquil.

TAPIA, M. 2000. Estudio del fitoplancton en la Isla Santa Clara durante febrero del 2001. Informe Técnico de INOCAR.

TAPIA, M. 2001. Contribución del fitoplancton para el estudio de impacto ambiental en el canal de acceso al Puerto Marítimo de Guayaquil. Informe Técnico de INOCAR.

TAPIA, M. 2002. Estudio de las comunidades del fitoplancton en los ríos Daule, Guayas y Estero Salado. (En Prensa).

Tapia M. \& G. Torres-Zambrano. 2000. Variabilidad fitoplanctónica en 5 bahías, Islas Galápagos (Ecuador). Acta Oceanográfica del Pacífico, 10: 151-159.

Torres-Zambrano, G. 1998. Variabilidad anual del fitoplancton marino en áreas costeras de $\mathrm{La}$ Libertad y Manta (Ecuador) y su interrelación con El Niño. Acta Oceanográfica del Pacífico, INOCAR, 9(1): 115-128.

Torres-Zambrano, G. \& M. TAPIA. 1998. Distribución del Primer Nivel Trófico (Fitoplancton) en el Pacífico Ecuatoriano, período 1996-1997 (Pre El Niño). Acta Oceanográfica del Pacífico, INOCAR, 9(1):79-94.

Torres-Zambrano G. \& M. Tapia. 2000. Distribución del fitoplancton y su comportamiento en el afloramiento en las Islas Galápagos. Acta Oceanográfica del Pacífico, 10 (1): 137-150.

Torres-Zambrano G. 2001. Ocurrencias de Mareas Rojas durante 1989-1999, en aguas ecuatorianas. Acta Oceanográfica del Pacífico, 10 (1): 127-136.

Torres G. 2002. Distribución del plancton en el mar ecuatoriano durante septiembre/2001. Acta Oceanográfica del Pacífico. (En Prensa). Trabajo presentado en las Jornadas Nacionales de Biología de noviembre/2001.

VILLAMAR, F. 1983a. Estudio taxonómico, sistemático y distribución de los poliquetos (Anélido) Bentónico 
Gayana 67(2), 2003

del Golfo de Guayaquil. Tesis Doctoral, Universidad de Guayaquil. Vol. X (1), Guayaquil, Ecuador.

Villamar, F. 1983b. Poliquetos bentónicos del Golfo de Guayaquil. Acta Oceanográfica del Pacífico, INOCAR. 2 (2): 659-733.

Villamar, F. 1986. Distribución de los poliquetos bentónicos del Golfo de Guayaquil. Acta
Oceanográfica del Pacífico. INOCAR. 3 (1).

VILlAMAR, F. 1989. Estudio de la macrofauna bentónica en el Golfo de Guayaquil, Exterior (Canal del Morro y Jambelí). Acta Oceanográfica del Pacífico. INOCAR. 5 (1).

Zambrano, I. 1983. Tintínidos del Golfo de Guayaquil. Acta Oceanográfica del Pacífico. INOCAR. 2 (2), 443-507.

Fecha de recepción: 06/05/03

Fecha de aceptación: 15/10/03 